\title{
Assessment of the Possible Reuse of Extractive Waste Coming from Abandoned Mine Sites: Case Study in Gorno, Italy
}

\author{
Neha Mehta ${ }^{1,2}$, Giovanna Antonella Dino ${ }^{1, *}$, Iride Passarella ${ }^{3}$, Franco Ajmone-Marsan ${ }^{4}$, \\ Piergiorgio Rossetti ${ }^{1}$ (D) and Domenico Antonio De Luca ${ }^{1}$ (I) \\ 1 Department of Earth Sciences, University of Turin, 10125 Torino, Italy; N.Mehta@qub.ac.uk (N.M.); \\ piergiorgio.rossetti@unito.it (P.R.); domenico.deluca@unito.it (D.A.D.L.) \\ 2 School of Mechanical and Aerospace Engineering, Queen's University Belfast, Belfast, BT9 5AH, UK \\ 3 Horizon s.r.l., 10095 Grugliasco (TO), Italy; iride.passarella@unito.it \\ 4 Department of Agricultural, Forestry and Food Sciences, University of Turin, 10095 Grugliasco (TO), Italy; \\ franco.ajmonemarsan@unito.it \\ * Correspondence: giovanna.dino@unito.it; Tel.: +39-011-6705150
}

Received: 21 January 2020; Accepted: 17 March 2020; Published: 21 March 2020

check for updates

\begin{abstract}
Supply of resources, a growing population, and environmental pollution are some of the main challenges facing the contemporary world. The rapid development of mining activities has produced huge amounts of waste. This waste, found in abandoned mine sites, provides the potential opportunity of extracting raw material. The current study, therefore, focuses on testing the validation of a shared methodology to recover extractive waste from abandoned mines, and applies this methodology to a case study in Gorno, northwest Italy. The methods focused on: (1) analyzing the impact of tailings and fine fraction of waste rock $(<2 \mathrm{~mm})$ on plants (Cress - Lepidium Sativum) to assess usability of both as soil additive, and (2) recovering raw materials from tailings and coarse fraction ( $>2 \mathrm{~mm}$ ) of waste rock, by means of dressing methods like wet shaking table and froth flotation. The results indicated that the fine fraction of waste rock and tailings did not have detrimental effects on seed germination; however, there was marked decrease in plant growth. As for the recovery of raw materials, the coarse waste rock samples, crushed to $<0.5 \mathrm{~mm}$, produced a recovery of $\mathrm{Cd}, \mathrm{Ga}$, and $\mathrm{Zn}$-as much as $66 \%, 56 \%$, and $64 \%$, respectively—using the wet shaking table. The same samples when crushed to $0.063-0.16 \mathrm{~mm}$ and used for froth flotation produced a recovery of $\mathrm{Cd}, \mathrm{Ga}$, and $\mathrm{Zn}$ of up to $61 \%, 72 \%$, and $47 \%$, respectively. The flotation experiment on tailings showed a recovery of $\mathrm{Cd}, \mathrm{Ga}$ and $\mathrm{Zn}$ at $\mathrm{pH} 7$ of $33 \%, 6 \%$ and $29 \%$ respectively. The present investigation highlights the methodologies used for extracting raw materials from extractive waste.
\end{abstract}

Keywords: circular economy; resource supply; raw materials; triassic western southern Alps (Italy); abandoned mines; extractive waste

\section{Introduction}

Raw materials are crucial for modern society. The evident growth and prosperity is based on mineral reserves and fossil fuels. The United Nations' Sustainable Development Goals, as well as implementation of the Paris Agreement, resulted in vast utilization of a wide range of minerals for green technologies, such as low-carbon applications [1]. This focus on growth, development, and increase in population has led to the scarcity of raw materials (RM) [2]. Economic development depends on the supply of RM [3-5] - in the European Union (EU) alone, 30 million jobs depend on access to raw materials [6]. 
In view of the recent developments, a list of 27 critical raw materials (CRM) was identified for EU nations in 2017. The crucial dependency on raw materials is acknowledged by the European Innovation Partnership on Raw Materials, which coordinates efforts across disciplines to tackle selected "grand challenges". One of the pillars of the EU Raw Materials Initiative focuses on the reuse and recycling of raw materials [6]. Moreover, the need to find RM and CRM has pushed the EU to adopt policies to promote the exploitation of waste from abandoned mining sites, termed as mining waste (also called as extractive waste-EW); and from productive cycles [7-9]. The term "extractive waste" is used in this paper. The use of extractive waste can result in recovery of RM and CRM, along with reclamation of polluted areas and development of an economic system that aims at minimizing waste and exploiting resources [10,11]. Indeed, using extractive waste for further extraction helps minimize waste production and consumption of unexplored resources: the amount of existing EW can be reduced by further exploiting the remaining valuable fractions, which in turn minimizes new waste generation by reducing the need for extracting unexplored resources. Consequently, the present study focuses on assessment of recovery of raw materials from EW and the effects of EW on plants, if used as an additive to soil from abandoned mines of Gorno in northwest Italy.

Considering the shortage of RM, research efforts should be directed towards the use of previously discarded EW [12]. This idea of reusing EW as integrative feeding materials for industrial processes is closely linked to the circular economy's perspectives, by integrating EW back into material cycles [13-19]. The potential for recovery of RM from extractive waste depends on several factors, such as their amount, concentration, and mineralogy; re-processing technology (commercially available and economically viable); and market demands [20].

Utilization of EW can offer both economic benefits and reduction in environmental impacts. Indeed, environmental legacies of mining sites are related to the presence of reactive minerals, sometimes of high economic value. Extractive waste can cause land degradation and contamination of water [21]. The reuse of EW may minimize the environmental impacts related to disposal; however, some reuse measures may actually cause new environmental problems. Considering this, care should be taken to perform life cycle assessment and cost-benefit analysis for handling waste on site [13].

\subsection{Relevant Literature}

The literature has shown that mineral waste streams can be reused and can be beneficial for extracting RM. A recent study by van Zyl [22] estimated that approximately 75 major tailing re-mining projects are taking place globally for the reclamation of copper, diamond, and gold. Another research concluded that the topsoil generated from dredge mining for heavy minerals such as rutile, ilmenite, and zircon in coastal dunes in Zululand, South Africa, since 1977 were used for the ecological restoration of abandoned mine areas by spreading the salvaged topsoil on tailing dumps to initiate natural succession and establishing dune forests [23]. Jiangang et al. [24] developed oil agglomeration flotation process for recovering molybdenite from tailings in Zhejiang province, China, while Ghosh et al. [25] showed recovery of Mn by bioleaching of ferro-manganese EW from Odisha, India, and Henne et al. [26] demonstrated recovery of copper from Cu-sulfide inclusions minerals of waste rock (WR) by bioleaching in the Salobo mine, Brazil. Another study in Pennsylvania, U.S.A reported rare earth elements and yttrium concentrations and other geochemical data from Appalachian Basin coal mine discharges and treatment precipitates collected from a variety of mine water and treatment environments [27]. In 2016, True North Gold Mine of Klondex Canada Limited in Manitoba, Canada, commenced a tailings reprocessing project [28]. The physicochemical, mineralogical, and elemental characterization of extractive waste from the exploitation of both iron ores and polymetallic minerals $(\mathrm{Pb}-\mathrm{Zn}-\mathrm{Ag})$ was done to evaluate the possibility of recovery of strategic elements, like $\mathrm{Ga}$, In, Ge, and rare earth elements (REE) in mining areas of México [29]. The recovery and upgradation of different REE from minerals were ascertained, especially brannerite, florencite, and stetindite from the iron oxide-silicate rich tailings (IST) generated at a South Australian mining operation using froth flotation [17]. Recently, a French geological survey identified interesting old mining wastes to assesses the potential metal 
recovery of these deposits with emphasis on critical metals for industrial development compiled by the European Commission in 2010. First, bioleaching tests conducted on tailing material from a lead-zinc mine near Freiberg (Germany) achieved zinc and indium yields of up to 80\% [30]. There are further studies that has been undertaken to depict the economic benefits by reusing waste generated from mines, for e.g., Pactwa et al. [31] presented economic and social benefits that can be obtained from lignite mine waste in Poland.

However, the research on implementation of circular economy principles in Italian abandoned mine sites is at the beginning stages and has still not been fully realized, despite the potential and growing interest in making the Italian economy more and more circular [32]. Moreover, the reuse and recovery of RM from waste depends on the type of the ore mined, waste typology, and geological and geographical setting of the area. Therefore, mining districts with EW should be analyzed in a site-specific manner to develop feasible reuse techniques.

\subsection{Study Objectives}

The present study, thus, focuses on preliminary assessment towards recovery of RM (such as $\mathrm{Zn}, \mathrm{Cd}$, and $\mathrm{Ga}$ ) from EW and the effects of EW as additive to soil from abandoned mines of Gorno in northwest Italy. However, the methodologies (Figure 1) applied for site investigation, sampling activities, extractive waste dressing activities to obtain raw materials and impact on plants can be replicated in similar contexts (e.g., mining site for $\mathrm{Zn}-\mathrm{Pb}$ exploitation). In a larger context, the approach followed in this research also depicts that traditional barriers between disciplines and sectors, and a holistic approach using knowledge of mining engineering, geology, separation and ore processing engineering (dressing methods), and soil science can lead to "sustainable mining".

\section{LANDFILL MINING APPROACH: FROM WASTE TO PRODUCTS}

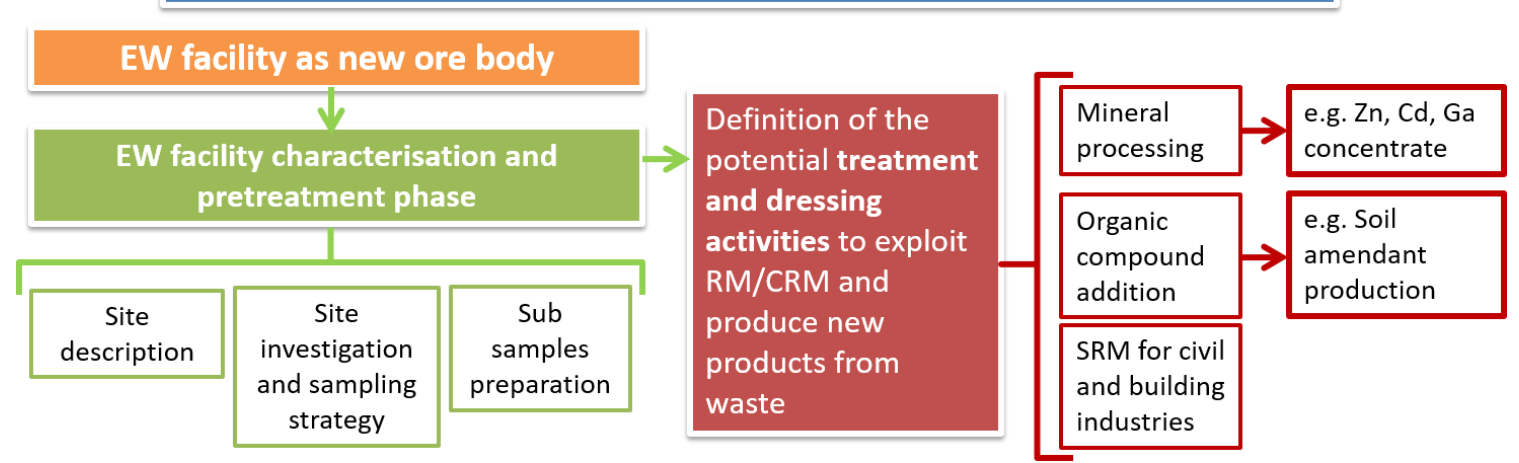

Figure 1. Schematic showing various steps to obtain products from extractive waste.

\section{Methodology}

The methodology followed (Figure 1) in this research consists of investigations, processes, and characterization steps, which can be replicated in similar case studies ( $\mathrm{Zn}-\mathrm{Pb}$ mining sites, but also extractive waste facilities at large). It can be considered an interdisciplinary approach to EW management and recovery in the view of a landfill mining approach. In particular, the steps followed during the research activity are:

1. Site description, which consists of collection of information about geology, mining, and processing activities (Section 2.1) [33]

2. Site investigation and sampling strategy (Section 2.2), which includes planned field survey to collect representative samples, define the investigating areas, evaluate waste characteristics, and estimate EW volumes [33]

3. Preparation of sub sample to be tested for RM/CRM recovery (Section 2.3) 
4. Definition of the potential treatment and dressing activities to exploit RM/CRM and produce new products from waste. The research is based on a preliminary separation into two main categories (size cut off $2 \mathrm{~mm}$ ), as described in Figure 2. In particular, the present paper presents two different chances to recover EW:

a. For the production of additive to soil (Section 2.4), which can be considered as the first step to produce substrate for rehabilitation and remediation purposes

b. For RM/CRM exploitation by means of common processing techniques as flotation and shaking table (Section 2.5).

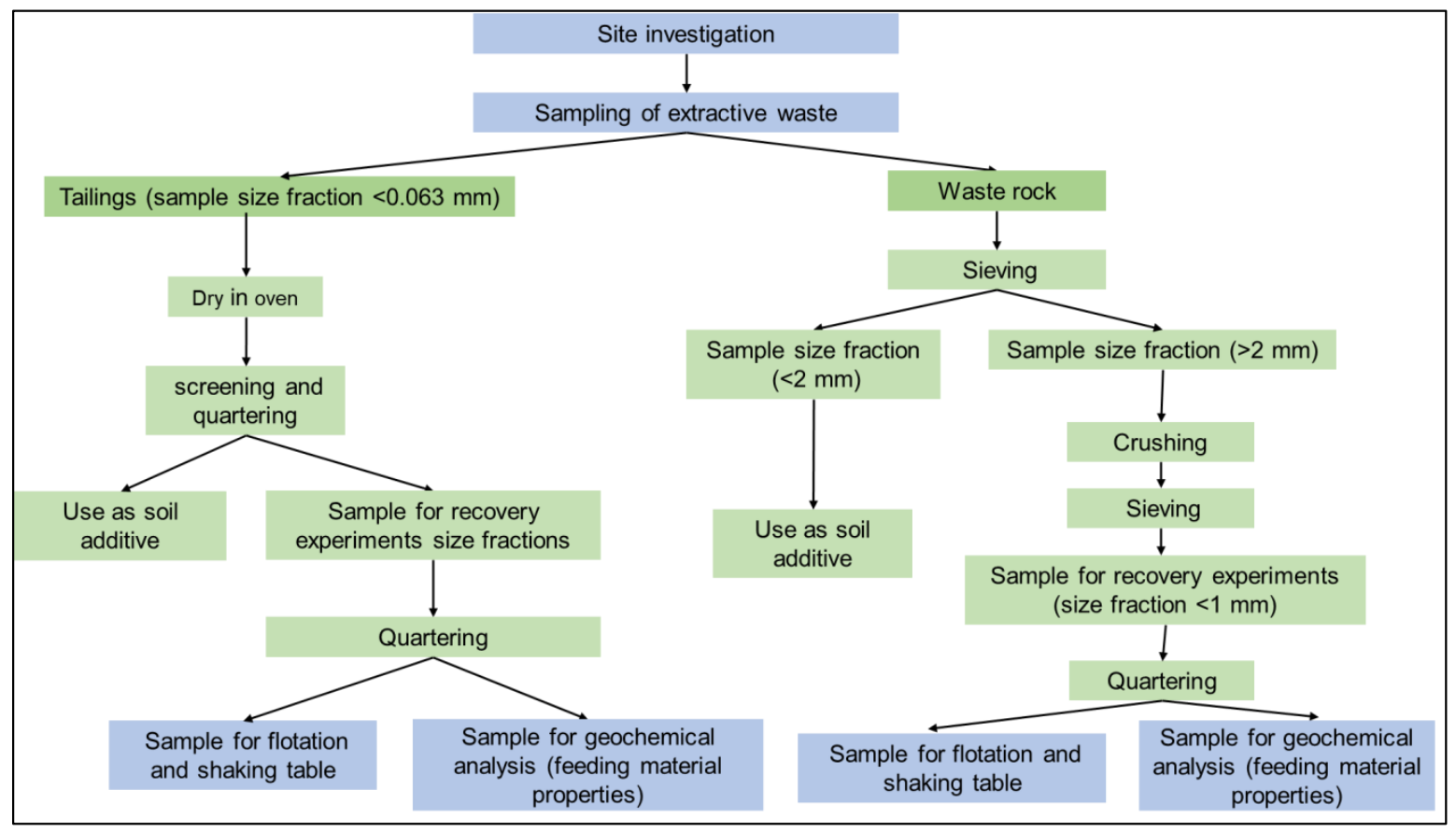

Figure 2. Flowchart showing preparation of subsamples.

\subsection{Study Site}

The Gorno mining site is located within the Seriana, Riso, and Brembana valleys (Lombardy, northwestern Italy) (Figure 2). It belongs to the Alpine type zinc-lead-silver stratabound ore deposits, associated with the middle Triassic carbonatic series. The mineralization ( $\mathrm{Zn}-\mathrm{Pb} \pm \mathrm{Ag} \pm \mathrm{baryte} \pm$ fluorite) mostly occurs within the "Metallifero" (i.e., "ore-bearing") formation of upper Ladinic-lower Carnian age [34-37]. Mining started in the Roman Age, but the beginning of industrial exploitation started in the 1837 and continued until 1982.

Primary mineralization is composed of sphalerite $(\mathrm{ZnS})$ and galena $(\mathrm{PbS})$, alongwith minor pyrite $\left(\mathrm{FeS}_{2}\right)$, marcasite $\left(\mathrm{FeS}_{2}\right)$, chalcopyrite $\left(\mathrm{CuFeS}_{2}\right)$, and argentite $\left(\mathrm{Ag}_{2} \mathrm{~S}\right)$. The dominant gangue minerals are calcite, dolomite, and quartz ( \pm ankerite). A secondary mineralization, composed of oxidation products of sphalerite, i.e., Zn-rich carbonate and silicate, was historically preferred for ore exploitation using underground mining activities. Consequently, the rocks with sphalerite and galena were separated and placed outside the tunnels excavated to access the underground ore deposit, forming several WR dumps across the whole district. However, the WR dumps in the Mount Arera are the biggest and easier to access, and, thus, most important as the study site. For the treatment of valuable ores, the flotation process was used (information from historic documents maintained by the Municipal Corporation of Gorno), leading to generation of tailings deposited close to Riso creek. Thus, the two types of EW present at the site are waste rock and tailings, produced due to primary separation and ore processing, respectively, of resources at the site. 


\subsection{Site Investigation and Sampling Strategy}

The sampling was performed in dumps placed at Mount Arera (Figure 3) following site investigation and sampling activities described in Dino et al. [33] and here briefly reported. The WR dumps at Mount Arera are spread uniformly with thickness of $c .2 \mathrm{~m}$. Waste rock material was sampled using a hand shovel and/or a hammer. Each sample $(8-10 \mathrm{~kg})$ was collected by recovering four subsamples from the vertices of a $2 \mathrm{~m} \times 2 \mathrm{~m}$ square, and mixing these together after removing organic residues. In total, 30 samples of waste rock were collected at the site in June 2016. Tailings deposit was near the Riso creek and covered with thin layer of soil of $20-40 \mathrm{~cm}$; hence, samples were taken using hand drilling, with an increasing depth from the ground. In total, 18 tailings samples were taken from four sampling points at the site.

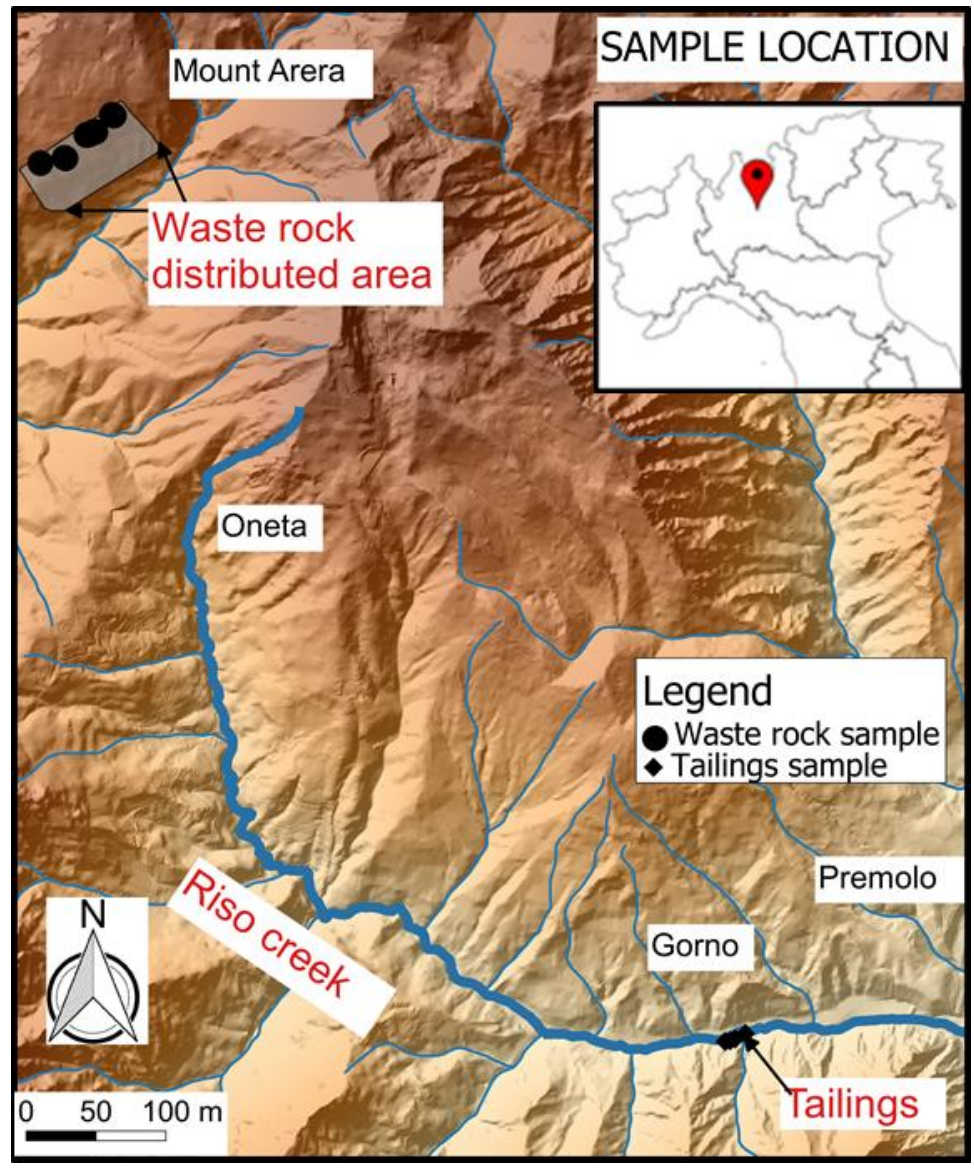

Figure 3. Sketch depicting sampling locations of extractive waste.

\subsection{Preparation of Subsamples}

Extractive waste subsamples were prepared as depicted in Figure 2. The waste rock samples from the site were air dried and sieved to obtain the samples in two different fractions i.e., fine fraction (size $<2 \mathrm{~mm}$ ) and coarse fraction (size $>2 \mathrm{~mm}$ ). The fine fractions from all samples were mixed to obtain a homogeneous mixture of waste. This waste was further used for analysis of impacts on plants to ascertain the possibility of its use as soil additive.

Similarly, the coarse fractions from the samples were mixed to obtain a homogeneous mix of WR in size fraction $>2 \mathrm{~mm}$. The obtained mix of WR samples was crushed by means of a jaw crusher, and sieved to obtain samples in size fraction $0-1 \mathrm{~mm}$. The sample in $0-1 \mathrm{~mm}$ was used for all the recovery experiments and quartered to obtain samples for dressing activities and chemical analysis of feed. Tailings from the site were dried in an oven at temperature of $100{ }^{\circ} \mathrm{C}$, for a period of $48 \mathrm{~h}$ to remove moisture. The dried samples were mixed to obtain homogeneous mix of tailings. The obtained 
sample was then screened to remove any organic residue and quartered to obtain a sample for use both as soil additive and dressing activities.

\subsection{Use of Extractive Waste as Soil Additive}

2.4.1. Aqua Regia Extracted Concentrations and Bioavailable Concentrations Analysis for Subsamples Used as Plant Additive

The waste rock ( $<2 \mathrm{~mm}$ fraction) and tailings were treated for analyzing their impacts on plants. The samples were analyzed for concentrations of chemical elements on the $<2 \mathrm{~mm}$ fraction using aqua regia U.S. EPA 3051 A, U.S. EPA 6050 C [38,39] and for bioavailable concentrations using diethylenetriaminepentaacetic acid (DTPA), in order to determine the different $\%(\mathrm{v} / \mathrm{v})$ of EW that could be used [40]. The detailed methods can be found in Supplementary Material S.1.

\subsubsection{Seed Germination and Plant Growth Experiments}

The seed germination test and plant growth experiments were conducted using Cress (Lepidium sativum) seeds [41,42]. The detailed methods can be found in Supplementary Material S.2. The results after the germination test (Equation (1)) and the plant growth test (Equation (2)) were calculated in terms of Germination Index and Plant Growth Index:

$$
\begin{gathered}
\mathrm{Ig}=\frac{G c \cdot L c}{G t \cdot L t} 100 \\
\mathrm{Gm}=\frac{B c}{B t} 100
\end{gathered}
$$

where Ig = Germination Index (in \%); Gc = mean value of germinated seeds using test solution; Gt = mean value of germinated seeds using control solution (double-distilled water); $\mathrm{Lc}=$ mean value of length of roots of seeds using test solution; $\mathrm{Lt}=$ mean value of length of roots of seeds using control solution; $\mathrm{Gm}=$ Plant Growth Index (in \%); $\mathrm{Bc}=$ weight of biomass of plants obtained using EW in sand and blond peat mixture; $\mathrm{Bt}=$ weight of biomass of plants obtained using only sand and blond peat mixture.

\subsection{Dressing Activities for Raw Materials Recovery}

\subsubsection{Total Concentrations Analysis and Mineralogical Analysis of Samples}

Prior to dressing activities, the analysis of subsamples used as feed for experiments was performed to ensure that extractive waste contained sufficient amounts of recoverable raw materials. The total concentrations of elements present in waste rock and tailings subsamples were analyzed at Activation Laboratories Ltd., Canada. The extraction solution for samples used hydrochloric, hydrofluoric, nitric, and perchloric acids for digestion (code: ultratrace 6). The digested solution was analyzed for element concentrations using inductively coupled plasma mass spectrometry and inductively coupled plasma optical emission spectrometry (ICP-MS and ICP-OES). Precision of the results was determined through the analysis of sample duplicates and blanks. Results of method blanks were always below detection limits. The detailed Quality Control measurements are in Supplementary Material S.3.

The mineralogical analysis of feed was not performed in this study, as it has been conducted on extractive waste from this site in a previous study by Dino et al. [33], which indicated the presence of sphalerite in the WR. However, tailings contained minor amounts of Fe sulphate, Zn-silicate (hemimorphite), Zn-carbonate (smithsonite and/or hydrozincite), and rare $\mathrm{Cu}$-As-Sb $\pm \mathrm{Pb}$ sulphosalt(s). In the current study, therefore, mineralogical analysis of selected heavy (concentrate) samples from shaking table experiments and float (concentrate) samples was performed to visualize and quantify the minerals present. The mineralogical analysis was performed using Micro- $X$-ray fluorescence (micro-XRF). X-ray maps of samples were acquired using a micro-XRF Eagle III-XPL spectrometer 
equipped with an EDS Si (Li) detector and with an EdaxVision32 micro-analytical system. The operating conditions were $4 \mu$ s counting time, $40 \mathrm{kV}$ accelerating voltage, and a probe current of $1000 \mu \mathrm{A}$. Quantitative modal percentages of each mineral have been obtained by processing the micro-XRF maps with the "Petromod" software [43].

\subsubsection{Wet Shaking Table}

The wet shaking table (also referred to as a shaking table in the present study) method was used for the dressing activity [44]. The experiment was performed on feed weighing $1000 \mathrm{~g}$ (Figure 4). After introducing the sample to the feed bar, a continuous flow of water was maintained on the table through a water distributor. The inclination of table, flow of water, and constant shaking of table led to the separation of feed into not-concentrate and concentrate tanks. Following the experiment, solutions containing light and heavy samples were filtered separately using a vacuum filter and Whatman filter papers of diameter $24 \mathrm{~cm}$. These samples were dried in an oven at $80{ }^{\circ} \mathrm{C}$ for $6 \mathrm{~h}$ to $24 \mathrm{~h}$ to remove moisture (until constant weight). The dried samples were weighed and quartered to obtain representative samples for analysis. These representative samples were analyzed for the concentrations of elements (geochemical analysis) and mineralogy (described in Section 2.5.1).

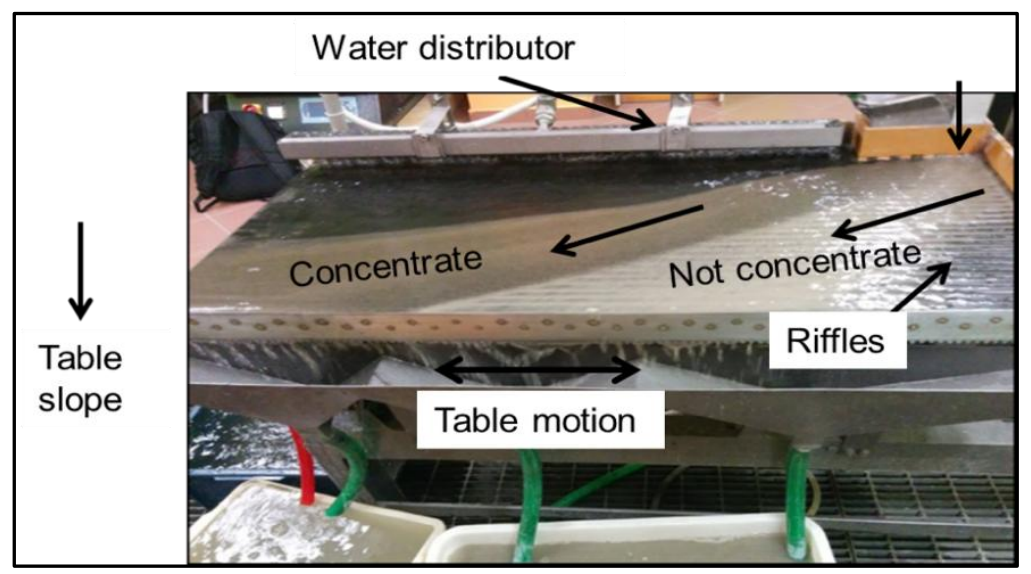

Figure 4. Photo captured during the wet shaking table experiment.

\subsubsection{Froth Flotation}

Subsamples for Flotation

Froth flotation (also referred to as flotation in subsequent sections) is a complex separation process that exploits the physicochemical surface properties of mineral particles to separate the valuable minerals present in the feed [45]. Since flotation utilizes surface properties, flotation of metal sulfides with dimensions $>0.5 \mathrm{~mm}$ is not feasible; therefore, the WR subsamples were prepared to be below $0.5 \mathrm{~mm}$ for flotation experiments [46]. The fractions $>0.5 \mathrm{~mm}$ were separated because at very high size fractions, the solid phase (comprising of primary minerals) to be floated is not fully liberated from other solid phases (consisting of gangue) in the mixture. The resultant composite particles can still be floated, but the separation is not satisfactorily selective. This is due to the fact that the concentrate obtained after flotation of very coarse size grains is unavoidably contaminated with the adjoining gangue [47].

The subsamples preparation for flotation experiments also included the removal of particles with size fractions $<0.063 \mathrm{~mm}$ for waste rock samples, using wet sieving. This was done because at very low sizes, gangue minerals are also finely grounded. These fine/ultrafine gangue particles not only affect sub-flotation processes in recovering valuable minerals based on true flotation, but also lead to high mechanical entrainment [48]. Mechanical entrainment is a transfer process by which mineral particles suspended in water enter the flotation froth, move upwards, and finally leave the flotation cell with 
the mineral particles recovered by true flotation, as explained by [49] (Figure 5). Since entrainment has a detrimental effect on the grade of the concentrate, it is advised to use the feeding with size $>50 \mu \mathrm{m}$ [48]. To account for these factors, grain liberation size experiments should be performed, which result in increased recovery of the minerals [48]. However, due to time limitations, these experiments were not carried out, and minimum size and maximum size were considered in a more general form, by crushing and sieving the coarse fraction of the WR in size fractions $(0.063-0.16 \mathrm{~mm}$ and $0.16-0.5 \mathrm{~mm})$. Such subsample preparation was not possible for tailings, as the original size of tailings was from 0-0.063 mm. Consequently, tailings were used for dressing activities, without any crushing from original size.

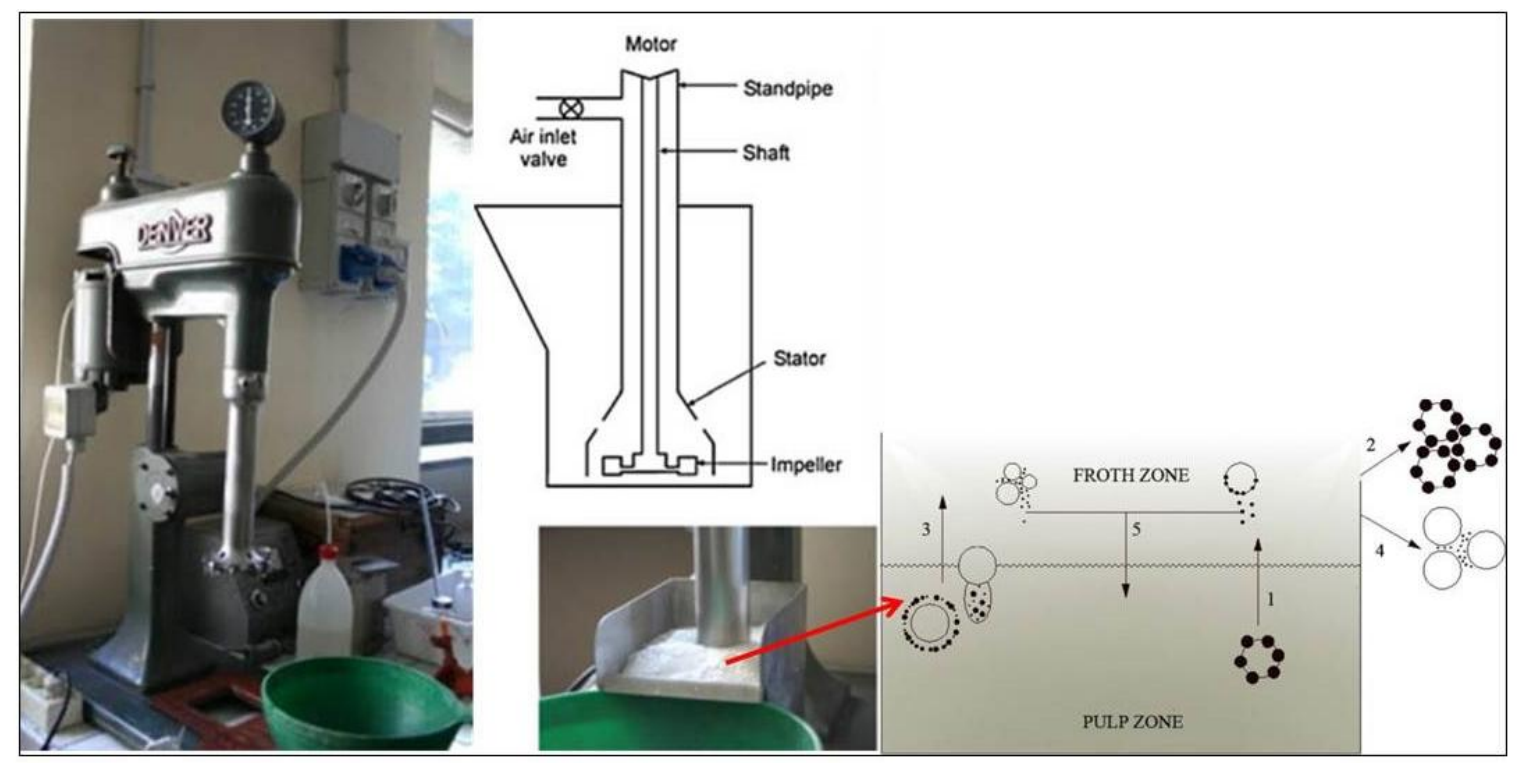

Figure 5. Photo of the Denver Cell used for froth flotation and the schematic diagram of the transportation of fully liberated mineral particles in a flotation cell (modified after [49]). The numbers represent: (1) Transportation of valuable mineral particles to the froth from the pulp by true flotation, (2) Transportation of valuable mineral particles to the concentrate from the froth by true flotation, (3) Transfer of mineral particles to the froth from the pulp by entrainment, (4) Transfer of entrained mineral particles to the concentrate from the froth by entrainment, and (5) Transfer of mineral particles from the froth to the pulp due to the drainage of detached particles and entrained particles.

\section{Chemical Reagents}

The waste and water mixture was prepared after mixing $200 \mathrm{~g}$ of waste sample in water, reaching up to a volume of $2600 \mathrm{~mL}$. The reagent solution was prepared using $1 \%(\mathrm{w} / \mathrm{v})$ of a commercially available reagent, known as Aeropromoter No. 825 (a product of American Cynamide Co.) in $1000 \mathrm{ml}$ of distilled water. The reagent was an anionic, petroleum-based sulfonate promoter. During the process of flotation, the collector is physically adsorbed on the surface of minerals by an electrostatic attraction. Adsorption of the collector on individual minerals can be controlled by the adjustment of $\mathrm{pH}$ of the system [50]. The experiments were thus conducted in slurry at $\mathrm{pH}$ of $7,8.5$, and 10 , to understand the effect of $\mathrm{pH}$ on the recovery of elements. The $\mathrm{pH}$ of the slurry was adjusted using $1 \mathrm{M} \mathrm{NaOH}$ instead of lime, which is mainly used in industrial flotation to eliminate the effect of $\mathrm{Ca}^{2+}$ on flotation [51].

\section{Experimental Procedure}

The extractive waste samples were treated using a self-aerating flotation Denver cell (Figure 5). During the experiments, the slurry was conditioned for two minutes. Following the addition of reagent dosage, the slurry was conditioned again for a period of two minutes. $20 \mathrm{~mL}$ of the reagent solution was added for size fraction $(0.063-0.16 \mathrm{~mm})$ of the sample weighing $200 \mathrm{~g}$, thus reaching reagent 
dosage of $1 \mathrm{~g} / \mathrm{kg}$. The $\mathrm{pH}$ of the slurry was then adjusted to a desired value, followed by conditioning of solution. Air was introduced into the slurry by the pumping action of an impeller. The air flow rate was controlled by the inlet valve and was correlated to the impeller speed, which was kept at $1500 \mathrm{rpm}$. The froth developed at the surface of the flotation cell was removed by hand using a paddle. The froth obtained was filtered to obtain a float sample, whilst the remaining slurry in the flotation cell was filtered to obtain a sink sample. These samples were dried and quartered to obtain representative samples, following the same process as in Section 2.5.2. The analysis was performed as explained in Section 2.5.1.

For waste rock samples in size fraction $(0.16-0.5 \mathrm{~mm})$, the experimental conditions like air flow rate and $\mathrm{pH}$ of the solution were maintained in a similar manner as that for fraction $0.063-0.16 \mathrm{~mm}$. However, reagent dosage was increased in comparison to reagent dosage used for fractions $0.063-0.16 \mathrm{~mm}$, to improve the flotation of particles (Figure 6). The reagent dosage was added in an incremental manner. Flotation was carried out by adding $20 \mathrm{~mL}$ reagent solution (dosage: $1 \mathrm{~g}$ of reagent for $1 \mathrm{~kg}$ of sample) and then removing the froth developed at the surface of the flotation cell. The froth developed at the surface of the flotation cell was removed by hand using a paddle. Another $20 \mathrm{~mL}$ of reagent was added to the solution left i.e., sink, after conditioning of three minutes, and maintaining $\mathrm{pH}$ similar to the $\mathrm{pH}$ of the starting solution. The float was separated again, followed by conditioning and addition of $20 \mathrm{~mL}$ of the reagent. Thus, $60 \mathrm{~mL}$ of the reagent was used in total for the solution of fractions $(0.16-0.5 \mathrm{~mm})$, taking the dosage to $3 \mathrm{~g} / \mathrm{kg}$ in total. Each time, air was introduced into the slurry by the pumping action of an impeller. The air flow rate was controlled by the inlet valve and was correlated to the impeller speed, which was kept at $1500 \mathrm{rpm}$. The analytical measurements were performed on all the three float samples from froth obtained due to addition of incremental reagent dosages and one sink sample. The sample preparation followed for these samples was similar to that followed for waste rock in size fraction $(0.063-0.16 \mathrm{~mm})$. The analysis was performed as explained in Section 2.5.1.

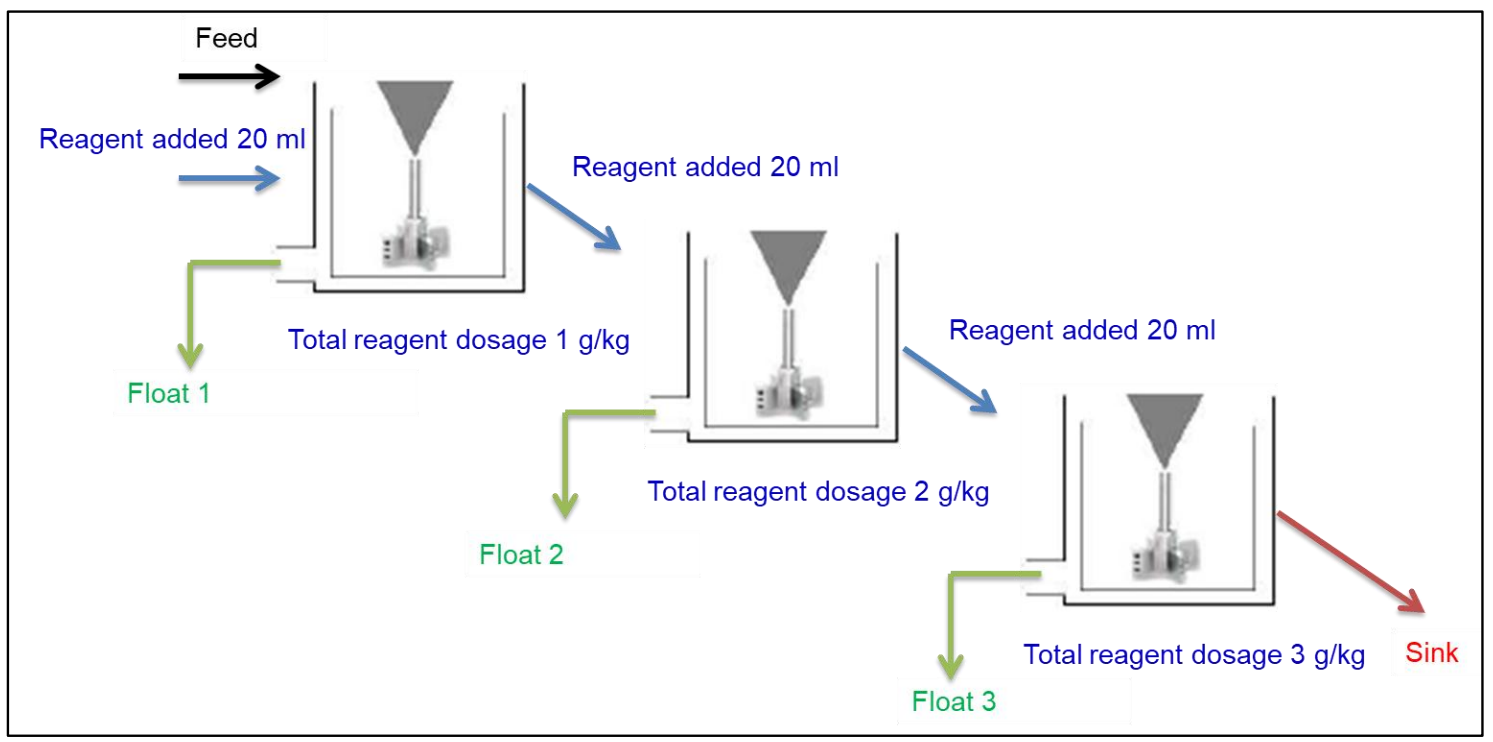

Figure 6. Schematic diagram representing the procedure followed for froth flotation for waste rock in size fraction $0.16-0.5 \mathrm{~mm}$ showing that after removing one set of float (concentrate), additional $20 \mathrm{~mL}$ of reagent was added to the solution up to total reagent dosage of $3 \mathrm{~g} / \mathrm{kg}$.

\subsubsection{Processing of Data}

The heavy and light samples from shaking table experiments and sink and float samples from flotation were analyzed for presence of elements using ICP-MS by the same methods described in Section 2.5.1. The recovery for weight of concentrate and for elements was calculated using Equations (3)-(5). In Equation (5), the weight of feed was taken as the sum of concentrate (i.e., heavy sample for shaking table and float sample for flotation experiments) and not concentrate (i.e., light 
sample for shaking table and sink sample for flotation experiments) weights. The concentrate and not concentrate weight were measured after the separation process and drying of samples, while the total concentrations analysis of concentrate and not concentrate led to the concentration of elements in $\mathrm{mg} / \mathrm{kg}$.

Thus, in Equation (5), the feed weight, concentrate weight and not concentrate weight were available from the weight measurements before and after dressing activities. The values of concentrations of metals were available for not concentrate and concentrate material from the chemical analysis. Therefore, the only unknown value that was calculated using these parameters was the concentration of elements in feed. Although the total concentrations' analysis results presented in Section 3.2.1 gave feed properties, this method based on mass balance was chosen to arrive at more precise and accurate calculations [45]. The obtained value of Feed $\mathrm{m}$ was used for both Equations (3) and (4).

$$
\begin{gathered}
\mathrm{Rw}=\frac{C w}{F w} 100 \\
\mathrm{Rm}=\frac{C m \cdot C w}{F m \cdot F w} 100 \\
\mathrm{Fm} \cdot \mathrm{Fw}=\mathrm{Cm} \cdot \mathrm{Cw}+\mathrm{Nm} \cdot \mathrm{Nw}
\end{gathered}
$$

where, $\mathrm{Cw}=$ weight of concentrate (i.e., heavy sample for shaking table and float sample for flotation experiments) after the dressing activities; $\mathrm{Cm}=$ concentration of a particular metal in concentrate solution in $\mathrm{mg} / \mathrm{kg} ; \mathrm{Fw}=$ weight of feed in $\mathrm{g} ; \mathrm{Fm}=$ concentration of metal in feed material in $\mathrm{mg} / \mathrm{kg}$; $\mathrm{Nw}=$ weight of not concentrate (i.e., light sample for shaking table and sink sample for flotation experiments) obtained after all reagent dosages; $\mathrm{Nm}=$ concentration of metal in not concentrate in $\mathrm{mg} / \mathrm{kg} ; \mathrm{Rw}=$ weight recovery (in \%); $\mathrm{Rm}=$ metal recovery (in \%).

As mentioned in Section 2.5.3, the flotation experiments on the WR in the size range fractions $0.16-0.5 \mathrm{~mm}$ were conducted using continuous addition of reagent dosage. After the addition of initial dosage $1 \mathrm{~g} / \mathrm{kg}$, the overflowing float was separated and the remaining slurry treated with another $20 \mathrm{~mL}$. In total, $3 \mathrm{~g} / \mathrm{kg}$ of reagent dosage was used in the process. Therefore, the results of recovery were calculated for every reagent dosage using Equations (6)-(10).

$$
\begin{gathered}
\mathrm{Ccw}(\mathrm{i})=\sum_{i=1}^{i} C w(i) \\
\mathrm{Ccm}(\mathrm{i})=\frac{\sum_{i=1}^{i} C w(i) \cdot C m(i)}{\sum_{i=1}^{i} C w(i)} \\
\mathrm{Fw} \cdot \mathrm{Fm}=\mathrm{Ccw}(3) \cdot \mathrm{Ccm}(3)+\mathrm{Nw} \cdot \mathrm{Nm} \\
\mathrm{CRw}(\mathrm{i})=\frac{C c w(i)}{F w} \cdot 100 \\
\mathrm{CRm}(\mathrm{i})=\frac{C c w(i) \cdot C c m(i)}{F w \cdot F m} \cdot 100
\end{gathered}
$$

where, $\mathrm{i}=$ the step of flotation in which calculations are performed according to reagent dosage (for e.g., $\mathrm{i}=1$, for dosage of $1 \mathrm{~g} / \mathrm{kg} ; \mathrm{i}=2$, for dosage of $2 \mathrm{~g} / \mathrm{kg}$ ); Ccw (i) = cumulative weight of float in $\mathrm{g}$ after (i) stages of flotation; $\mathrm{Ccm}$ (i) = cumulative concentration of metal obtained in float in $\mathrm{mg} / \mathrm{kg}$ after (i) stages of flotation; $\mathrm{Cw}$ (i) = weight of float sample(s) after (i) stages of reagent addition in $\mathrm{g} ; \mathrm{Cm}$ (i) = concentration of float after (i) stages of reagent addition in $\mathrm{mg} / \mathrm{kg}$; $\mathrm{Fw}=$ weight of feed in $\mathrm{g}$; $\mathrm{Fm}=$ concentration of metal in feed in $\mathrm{mg} / \mathrm{kg}$; $\mathrm{Nw}=$ weight of sink obtained after all reagent dosages in $\mathrm{g}$ i.e., completion of flotation; $\mathrm{Nm}=$ concentration of metal in sink in $\mathrm{mg} / \mathrm{kg}$ i.e., completion of flotation; $\mathrm{CRw}(\mathrm{i})=$ Cumulative recovery of weight achieved after (i) stages of flotation; $\mathrm{CRm}$ (i) = cumulative metal recovery obtained after (i) stages of flotation. 


\section{Results and Discussion}

\subsection{Impact of Extractive Waste on Plants}

3.1.1. Aqua Regia Extractable Concentrations and Bioavailable Concentrations Analysis on Fine Fraction of Extractive waste

Aqua regia does not result in complete dissolution of elements bound or occluded into silicate lattices [52], thus providing only a pseudo-total concentration. However, it is commonly used in environmental studies for the assessment of extent of soil and EW contamination because this acid blend usually addresses the most concerning chemical fraction for environment and human health $[53,54]$. The aqua regia extractable and bioavailable concentrations on the EW samples with size fraction $<2 \mathrm{~mm}$ are shown in Table 1 . It should be noted that size fraction $<2 \mathrm{~mm}$ was considered for these experiments, following the Italian legislation about characterization of waste materials to evaluate impacts on the environment [55]. Waste rock sample recorded the aqua regia extractable concentrations of As as $143 \mathrm{mg} / \mathrm{kg}$, $\mathrm{Cu}$ as $868 \mathrm{mg} / \mathrm{kg}, \mathrm{Ni}$ as $1063 \mathrm{mg} / \mathrm{kg}$, and Sb as77 mg/kg. The aqua regia extractable concentrations of $\mathrm{Cd}(260 \mathrm{mg} / \mathrm{kg})$ and $\mathrm{Zn}(147,367 \mathrm{mg} / \mathrm{kg}$ i.e., $148 \mathrm{~g} / \mathrm{kg})$ were found to be very high due to the parent material. The results, therefore, showed that the aqua regia extractable concentrations of $\mathrm{As}, \mathrm{Cd}, \mathrm{Cu}, \mathrm{Ni}, \mathrm{Sb}$, and $\mathrm{Zn}$ were higher than the Italian permissible limits for soil for both industrial uses and recreational and habitation uses [55]. However, not all the elements were bioavailable to plants. The bioavailability analysis using DTPA showed that $\mathrm{Cd}$ and $\mathrm{Zn}$ were the only elements in waste rock that showed very high bioavailable concentrations. This is due to the fact that availability and bioavailability of metals, non-metals, and metalloids is low in materials from calcareous rocks due to prevailing alkaline $\mathrm{pH}$ values [56].

Table 1. Aqua regia extractable concentrations and bioavailable concentrations $(\mathrm{mg} / \mathrm{kg})$ in waste rock and tailings sample ( $<2 \mathrm{~mm}$ size fraction).

\begin{tabular}{|c|c|c|c|c|c|c|c|c|c|c|c|c|c|c|}
\hline \multirow[t]{2}{*}{ Sample } & & $\mathrm{pH}$ & As & $\mathrm{Be}$ & $\mathrm{Cd}$ & Co & $\mathrm{Cr}$ & $\mathrm{Cu}$ & $\mathrm{Ni}$ & $\mathbf{P b}$ & $\mathrm{Sb}$ & $\mathrm{Tl}$ & V & $\mathrm{Zn}$ \\
\hline & & $\begin{array}{c}\left(\mathrm{H}_{2} \mathrm{O}\right) \\
1: 2.5\end{array}$ & \multicolumn{12}{|c|}{$\mathrm{mg} / \mathrm{kg}$} \\
\hline \multirow{4}{*}{$\begin{array}{c}\text { Waste } \\
\text { rock }\end{array}$} & Limit A & & 20 & 2 & 2 & 20 & 150 & 120 & 120 & 100 & 10 & 1 & 90 & 150 \\
\hline & Limit B & & 50 & 10 & 15 & 250 & 800 & 600 & 500 & 1000 & 20 & 10 & 250 & 1500 \\
\hline & Total & \multirow{2}{*}{8.14} & 143 & 0 & 260 & 100 & 24 & 868 & 1063 & 101 & 77 & 0 & 76 & 147,367 \\
\hline & Bio & & 0 & 0 & 9 & 0 & 0 & 1 & 0 & 0 & 0 & 0 & 0 & 733 \\
\hline \multirow{2}{*}{ Tailings } & Total & \multirow{2}{*}{8.25} & 84 & 0 & 34 & 2 & 7 & 236 & 5 & 1919 & 163 & 0 & 29 & 10,338 \\
\hline & Bio & & 0 & 0 & 1 & 0 & 0 & 110 & 0 & 41 & 0 & 0 & 0 & 507 \\
\hline
\end{tabular}

Total: Concentration $(\mathrm{mg} / \mathrm{kg})$ of elements using aqua regia, Bio: Bioavailable concentration $(\mathrm{mg} / \mathrm{kg})$ using DTPA extractions. Limit A denotes the permissible limits for recreational and habitation areas and Limit B represents the permissible limits for industrial areas [55].

Samples of tailings recorded the aqua regia extractable concentration of As, $\mathrm{Cd}$, and $\mathrm{Cu}$ as 84,34 , and $236 \mathrm{mg} / \mathrm{kg}$, respectively. The aqua regia extractable concentration of $\mathrm{Pb}$ and $\mathrm{Zn}$ were very high and reached 1919 and 10,338 mg/kg, respectively. The concentration of $\mathrm{As}, \mathrm{Cd}, \mathrm{Cu}, \mathrm{Pb}$, and $\mathrm{Zn}$ obtained using aqua regia were higher in tailings in comparison to Italian limit for recreational and habitation uses. The results of bioavailability analysis showed that the bioavailable concentration of $\mathrm{Cu}$ and $\mathrm{Zn}$ were high.

\subsubsection{Seed Germination and Plant Growth}

The results of the seed germination test (Figure 7a) indicated that $75 \%$ of the test solution from extractive waste with double-distilled water led to a Germination Index of 95\%, suggesting that there was no major detrimental impact to seed germination. The results of plant growth test (Figure 7b) showed that there was a decrease in plant growth with increase in WR and tailings content in the sand and blond peat mixture (blond peat is a stick-free peat that allows suitable contact between seed and 
substrate, promoting uniform seed germination). The addition of $10 \%, 20 \%$, and $30 \%$ of fine fraction of WR during the pot experiments led to Plant Growth Index of $46 \%, 33 \%$, and $40 \%$ respectively, implying sharp decrease in plant growth even after addition of WR. This can be ascribed to: (1) Cd and $\mathrm{Zn}$ toxicity to plants due to WR. Indeed, $\mathrm{Cd}$ tends to be toxic to plant growth even at very low concentrations by interfering with the uptake, transport, and use of elements (e.g. $\mathrm{Ca}, \mathrm{Mg}$, $\mathrm{P}$, and $\mathrm{K}$ ) by plants [57]; (2) Lesser availability of nutrients and organic matter due to the addition of WR.

(a)

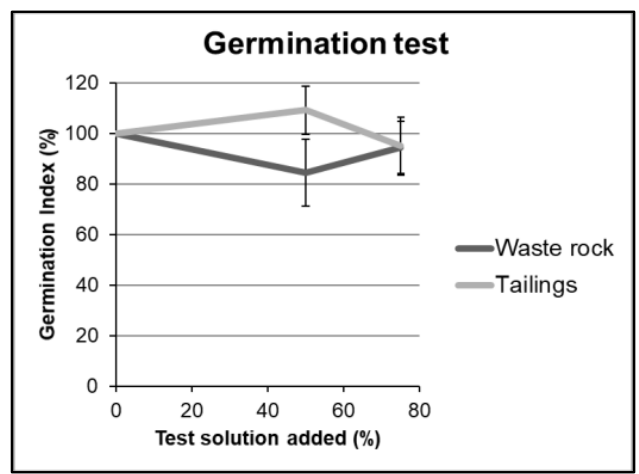

(b)

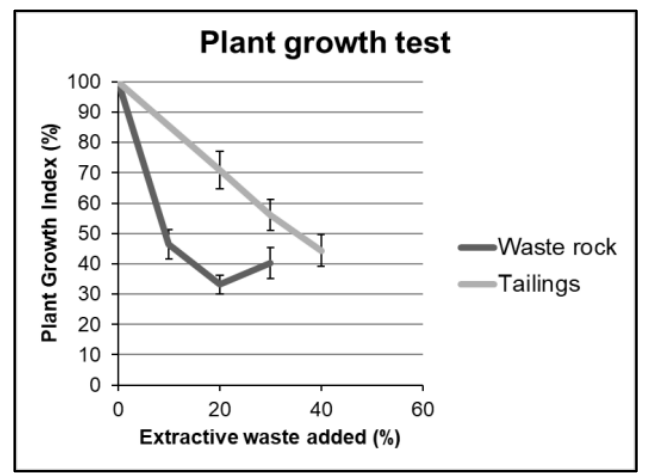

Figure 7. Germination Index (a) I and Plant Growth Index (b) using waste rock and tailings from Gorno.

The results of plant growth for tailings recorded that the addition of $20 \%, 30 \%$, and $40 \%$ of tailings to the mixture led to Plant Growth Index of $71 \%, 56 \%$, and $44 \%$ respectively, exhibiting that mixtures prepared with addition of tailings was less harmful than mixture with WR. One of the major factors contributing to this observation could be lesser aqua regia extractable and bioavailable concentrations (as shown in Section 3.1.1) of elements in tailings compared to WR.

These results serve as an indication of the impact of extractive waste on plants so as to assess the usability of extractive waste as soil additives. The results recorded that in the present form and without the use of amendments and fertilizers, the extractive waste samples cannot be used for growing plants. Further experiments to confirm the uses of waste rock as soil additive are required, which takes into account the effect of WR on different kind of plants and the translocation of absorbed elements from roots to aerial parts of the plant body. It should also be noted that plant growth could be increased by: (a) addition of amendments, (b) selection of appropriate plant species, and (c) addition of fertilizers [58]. A study conducted by Dalmora et al. [59] demonstrated that the use of vesicular andesite powder as a soil remineralizer in agriculture may be suitable for solving the problem of by-products deposited outside the mines and to decrease the consumption of highly soluble fertilizers, which should also be considered to use the extractive wastes as soil additive.

\subsection{Dressing Activities}

\subsubsection{Feed Characteristics}

The subsamples of coarse fraction ( $>2 \mathrm{~mm}$ ) of WR crushed to size fractions of $<0.5 \mathrm{~mm}$ and $0.5-1 \mathrm{~mm}$ were analyzed for total concentrations of elements prior to dressing activities. Similar analysis was performed on tailings. In general, it was observed that concentrations of the elements in the samples of WR in size fraction $<0.5 \mathrm{~mm}$ were higher compared to samples in $0.5-1 \mathrm{~mm}$ size fraction [60]. It could be due to the fact that concentration tends to be higher at smaller sizes, as smaller sizes provide more specific area. The samples were found to contain very high zinc concentrations reaching up to $100,000 \mathrm{mg} / \mathrm{kg}$ (i.e., $100 \mathrm{~g} / \mathrm{kg}$ ) for size fraction $<0.5 \mathrm{~mm}$ and $84,000 \mathrm{mg} / \mathrm{kg}$ (i.e., 84 $\mathrm{g} / \mathrm{kg}$ ) for size fraction $0.5-1 \mathrm{~mm}$ of the total weight of samples. Tailings recorded total concentration of $\mathrm{Zn}$ as $7640 \mathrm{mg} / \mathrm{kg}$ (i.e., $7.64 \mathrm{~g} / \mathrm{kg}$ ), as shown in Table 2. Concentration of $\mathrm{Ga}$ in waste rock with size fraction $<0.5 \mathrm{~mm}$, WR with size fraction $0.5-1 \mathrm{~mm}$ and tailings were found to be $11.4,15.4$, and $2.1 \mathrm{mg} / \mathrm{kg}$, respectively. Cadmium concentrations were also noticed to be high, ranging from $36 \mathrm{mg} / \mathrm{kg}$ 
in tailings to $316 \mathrm{mg} / \mathrm{kg}$ in WR. Considering high concentrations of $\mathrm{Cd}, \mathrm{Ga}$, and $\mathrm{Zn}$ in tailings and WR, the calculations of weight recovery and metal recovery were performed on these elements. It was also noticed that concentrations of many of the elements apart from $\mathrm{Cu}$ and $\mathrm{Pb}$ were higher in waste rock compared to tailings.

Table 2. Total concentrations $(\mathrm{mg} / \mathrm{kg}$ ) analyzed using hydrochloric, hydrofluoric, nitric, and perchloric acids for digestion. The analysis was performed on subsamples of waste rock and tailings.

\begin{tabular}{ccccccccccccccc}
\hline Sample & & Be & Cd & Co & $\mathbf{C r}$ & $\mathbf{C u}$ & $\mathbf{G a}$ & $\mathbf{N i}$ & $\mathbf{P b}$ & $\mathbf{S b}$ & $\mathbf{T l}$ & $\mathbf{V}$ & $\mathbf{Z n}$ \\
\hline Waste & $<0.5 \mathrm{~mm}$ & 0.3 & 270 & 3 & 10 & 73 & 11.4 & 5.6 & 20.2 & 77 & 0.2 & 32 & 100,000 \\
rock & $0.5-1 \mathrm{~mm}$ & 0.3 & 316 & 1.1 & 9 & 77 & 15.4 & 3.4 & 40.8 & 0 & 0.2 & 31 & 84,000 \\
Tailings & $<0.063 \mathrm{~mm}$ & 0.7 & 36 & 1.7 & 9 & 261 & 2.1 & 3.1 & 1420 & 163 & 0.6 & 35 & 7640 \\
\hline
\end{tabular}

\subsubsection{Shaking Table}

Figure 8a depicts that the weight recovery for WR for $<0.5 \mathrm{~mm}$ and $0.5-1 \mathrm{~mm}$ was nearly similar. However, the recovery of $\mathrm{Cd}, \mathrm{Ga}$, and $\mathrm{Zn}$ was found to be different in both the size fractions (Figure $8 \mathrm{~b}$ ). The waste rock samples in the size fraction $<0.5 \mathrm{~mm}$ recorded the recovery of $\mathrm{Cd}, \mathrm{Ga}$, and $\mathrm{Zn}$ as $66 \%$, $56 \%$, and $64 \%$ respectively. While, shaking table of WR samples in size fraction $0.5-1 \mathrm{~mm}$ led to the recovery of $\mathrm{Cd}, \mathrm{Ga}$, and $\mathrm{Zn}$ as $39 \%, 39 \%$, and $43 \%$ respectively. The possible reasons for the decrease in recovery and separation efficiency with respect to increase in size could be that for some minerals, coarse grains are nearly equi-dimensional, and the difference in specific gravity between those grains is not sufficient, that it can lead to proper separation [61].

The shaking table experiments on tailings showed the weight recovery as 3.7\%. The recovery of $\mathrm{Cd}, \mathrm{Ga}$, and $\mathrm{Zn}$ was $2 \%, 7 \%$, and $4 \%$, respectively (Figure $8 \mathrm{c}$ ). It was observed that tailings showed lesser recovery than waste rock, which could be due to the fact that tailings in Gorno mining area were generated after processing of original ores, leading to alteration of surface properties of minerals and the material in a way that is not suitable for separation of minerals, while the WR tends to preserve the characteristics of original rock formations.

The mineral maps of the heavy sample after shaking table for waste rock $(<0.5 \mathrm{~mm})$ showed that sphalerite (83.6\%) and calcite (13.7\%) were the most abundant minerals. Minor minerals were pyrite, quartz, and dolomite (Figure 9a). Mapping of heavy sample after shaking table for WR $(0.5-1 \mathrm{~mm})$ depicted that abundant minerals obtained after shaking table were sphalerite $(49.3 \%)$ and dolomite $(43.3 \%)$. The minor minerals were smithsonite $(3.8 \%)$, calcite $(2.9 \%)$, quartz $(0.6 \%)$, and pyrite $(0.15 \%)$ (Figure 9b). The samples from WR in both size fractions show that the shaking table treatment of WR can lead to beneficial recovery of $\mathrm{Zn}$, present as sphalerite $(\mathrm{ZnS})$ and subordinately in smithsonite $\left(\mathrm{ZnCO}_{3}\right)$. However, sphalerite was more in heavy samples obtained from WR in size fraction $(<0.5 \mathrm{~mm})$ than that in size fraction $(0.5-1 \mathrm{~mm})$. This was also evident in recovery of metals summarized in Figure 8. Mapping of a heavy sample of tailings demonstrated that abundant minerals were calcite $(88.5 \%)$ and pyrite $(10.0 \%)$; and minor minerals were sphalerite, dolomite, and galena, with total percentage of less than $5 \%$ (Figure 9c). These results reveal that the heavy samples from tailings did not show any major presence of sphalerite, which can be exploited economically. 
(a)

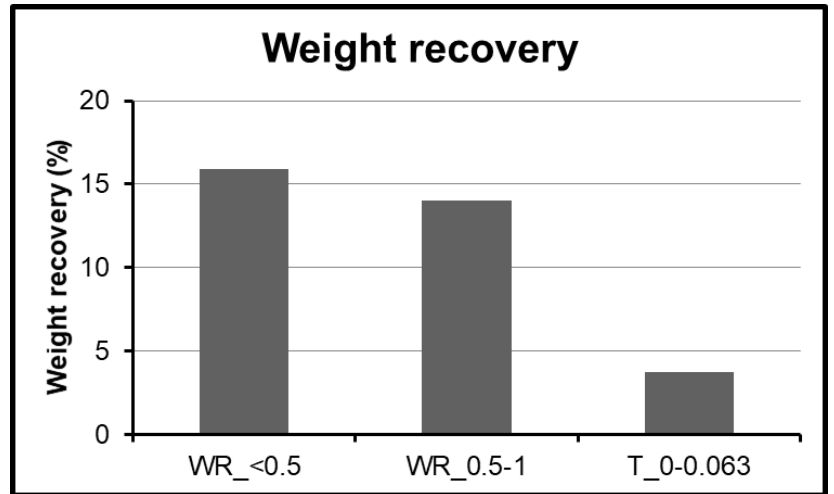

(b)

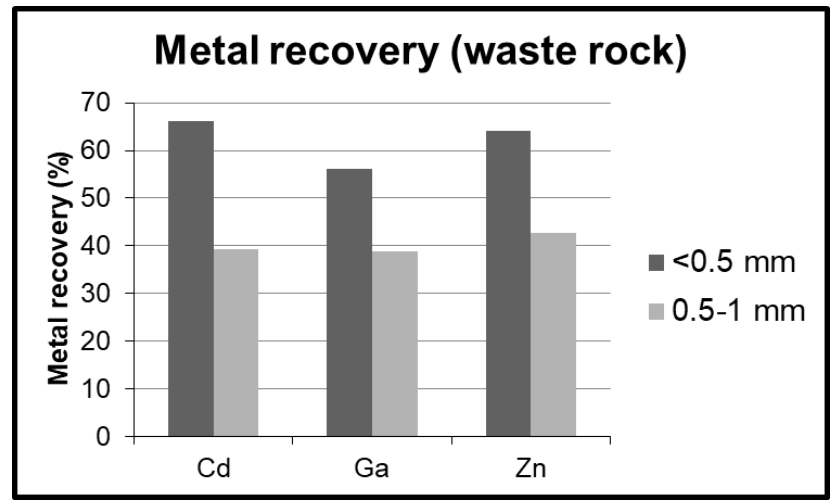

(c)

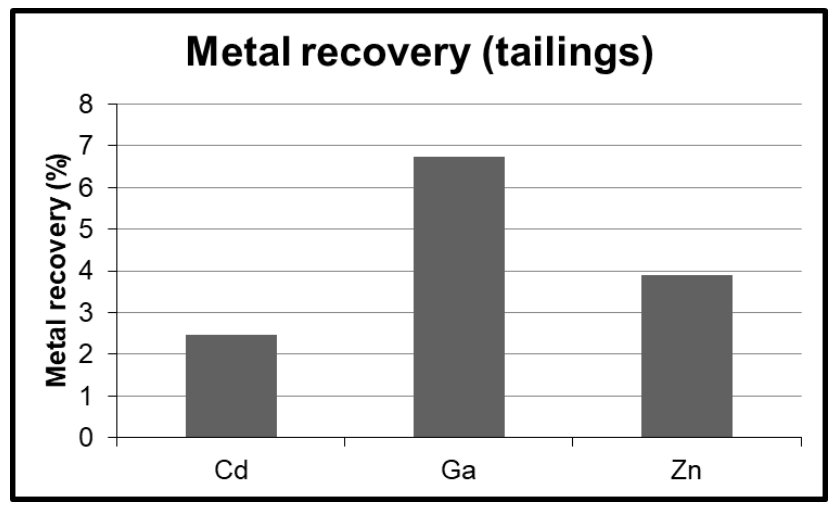

Figure 8. Weight recovery and metal recovery obtained after shaking table experiments. (a) Weight recovery of WR in size fraction $<0.5 \mathrm{~mm}\left(W R \_<0.5\right)$ and size fraction 0.5-1 mm (WR_0.5-1) and tailings; (b) Recovery of $\mathrm{Cd}, \mathrm{Ga}$, and $\mathrm{Zn}$ using waste rock; (c) Recovery of $\mathrm{Cd}$, Ga, and Zn using tailings during shaking table experiments. 
(a)

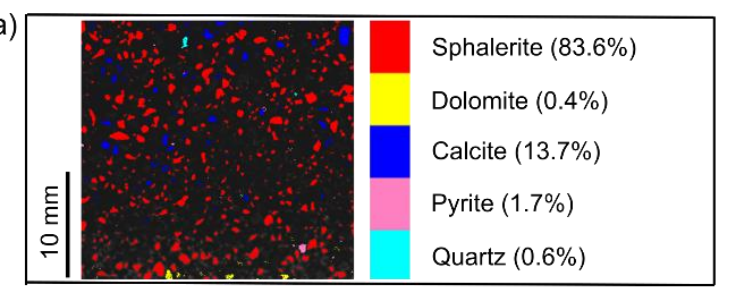

(b)

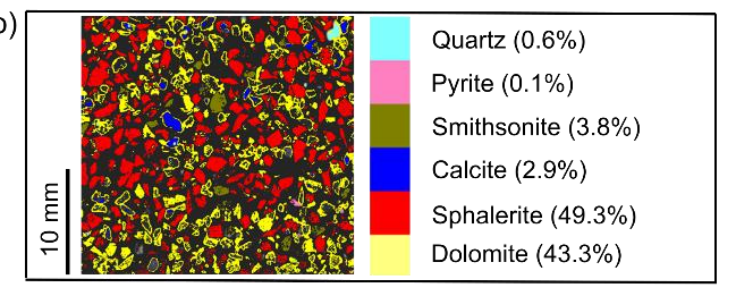

(c)

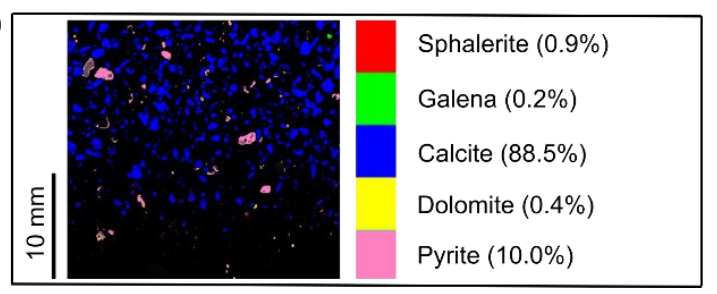

Figure 9. Mineral maps of heavy samples obtained after shaking table experiments of (a) waste rock (size fraction $<0.5 \mathrm{~mm}$ ), (b) waste rock (size fraction 0.5-1 mm), and (c) tailings.

\subsubsection{Flotation}

Flotation experiments were conducted on waste rock in size fractions $0.063-0.16 \mathrm{~mm}$ and $0.16-0.5 \mathrm{~mm}$. The recovery for WR and tailings samples using $1 \mathrm{~g} / \mathrm{kg}$ of reagent dosage were calculated using Equations (3)-(5), plotted in Figure 10. The weight recovery of WR samples in different size fractions and tailings tends to increase with increase in $\mathrm{pH}$. It was also noticed that recovery for analyzed metals was lesser than $50 \%$ for extractive waste samples at reagent dosage of $1 \mathrm{~g} / \mathrm{kg}$ at all three $\mathrm{pH}$ conditions. For the WR in the size fraction $0.063-0.16 \mathrm{~mm}$, at dosage of $1 \mathrm{~g} / \mathrm{kg}$, the weight recovery was $37.3 \%, 44.6 \%$, and $53.2 \%$, respectively. The recovery of $\mathrm{Cd}$ at $\mathrm{pH} 7,8.5$, and 10 was $49 \%, 43 \%$, and $36 \%$, respectively. The recovery of $\mathrm{Ga}$ at different $\mathrm{pH}$ conditions was $45 \%$ (at $\mathrm{pH} 7$ ), $38 \%$ (at pH 8.5), and 32\% (at pH 10). The recovery of $\mathrm{Zn}$ at $\mathrm{pH} 7,8.5$, and 10 was $37 \%, 36 \%$, and $36 \%$, respectively. Thus, the recovery for flotation followed the trend $\mathrm{pH} 7>\mathrm{pH} 8.5 \geq \mathrm{pH} 10$.

For the WR $(0.16-0.5 \mathrm{~mm})$ at dosage of $1 \mathrm{~g} / \mathrm{kg}$, the weight recovery was found to vary from $8.8 \%$ to $19.0 \%$ with increase in $\mathrm{pH}$ from 7 to 10 . The recovery of $\mathrm{Cd}$ at $\mathrm{pH} 7,8.5$ and 10 was $9 \%, 7 \%$, and $14 \%$, respectively. The recovery of $\mathrm{Ga}$ at different $\mathrm{pH}$ conditions was $8 \%$ (at $\mathrm{pH} 7$ ), $6 \%$ (at pH 8.5), and $12 \%$ (at $\mathrm{pH} 10$ ). The recovery of $\mathrm{Zn}$ at $\mathrm{pH} 7,8.5$, and 10 was $2 \%, 2 \%$, and $8 \%$, respectively. Thus, the results showed that by keeping all the experimental conditions constant, the recovery for flotation followed the trend $\mathrm{pH} 10>\mathrm{pH} 7>\mathrm{pH}$ 8.5. The trend of recovery with respect to $\mathrm{pH}$ of slurry was different for varying size fractions. These results lead to the conclusion that the $\mathrm{pH}$ of the slurry affects the separation efficiency differently for different size fractions.

These results depicted that recovery of $\mathrm{Cd}, \mathrm{Ga}$, and $\mathrm{Zn}$ from WR samples at reagent dosage of $1 \mathrm{~g} / \mathrm{kg}$ was higher for samples with size fraction $0.016-0.5 \mathrm{~mm}$, compared to $0.063-0.16 \mathrm{~mm}$. The possible reason could be that the reagent dosage required to facilitate the flotation in higher size fractions could be large, which has been evident in the latter part of this section, where the recovery tends to increase with the increase in reagent dosage.

The flotation experiment on tailings showed that the recovery of $\mathrm{Cd}$ and $\mathrm{Zn}$ at $\mathrm{pH} 7$ was 33\% and $29 \%$, respectively. It was observed that with increase in $\mathrm{pH}$, there was increase in recovery of the elements as well, for e.g., at $\mathrm{pH} 8.5$, the recovery of $\mathrm{Cd}$ and $\mathrm{Zn}$ was $40 \%$ and $35 \%$, respectively. With $\mathrm{pH} 10$, the highest recovery was obtained. The metal recovery of tailings was not very high; 
the possible reason could be that the mechanical entrainment, which leads to transport of gangue material with mineral particles increases with increase in percentage of fine particles [62]. It is more likely to operate on fine particles, which are prone to be carried over in liquid due to relatively low mass (refer to Figure 6 for entrainment explanation). The mechanical entrainment of gangue, therefore, leads to low quality of the concentrate from flotation processes [48]. It should be noted that all the recovery results presented here for flotation experiments include the particle recovery by true flotation and mechanical entrainment.

(a)

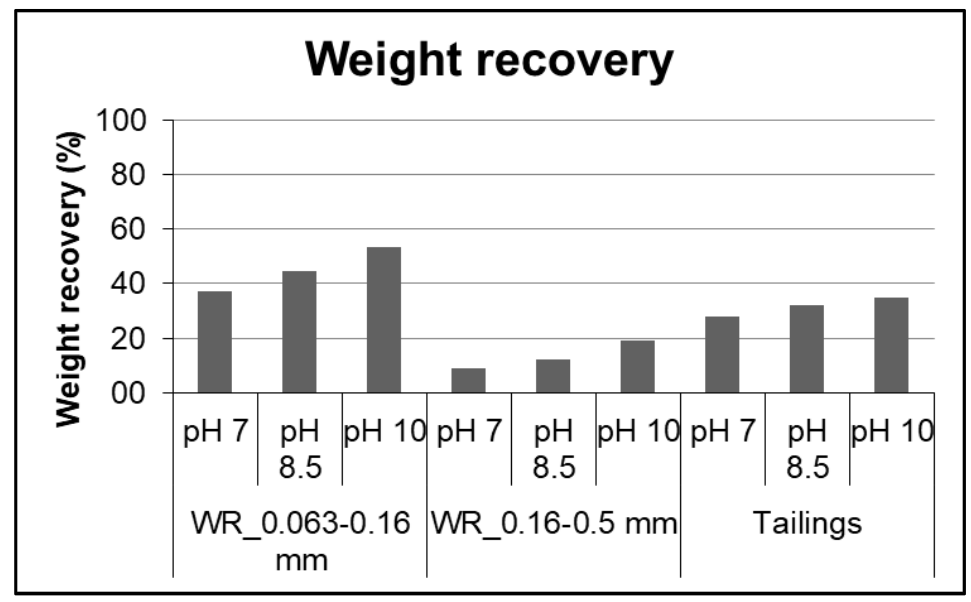

(b)

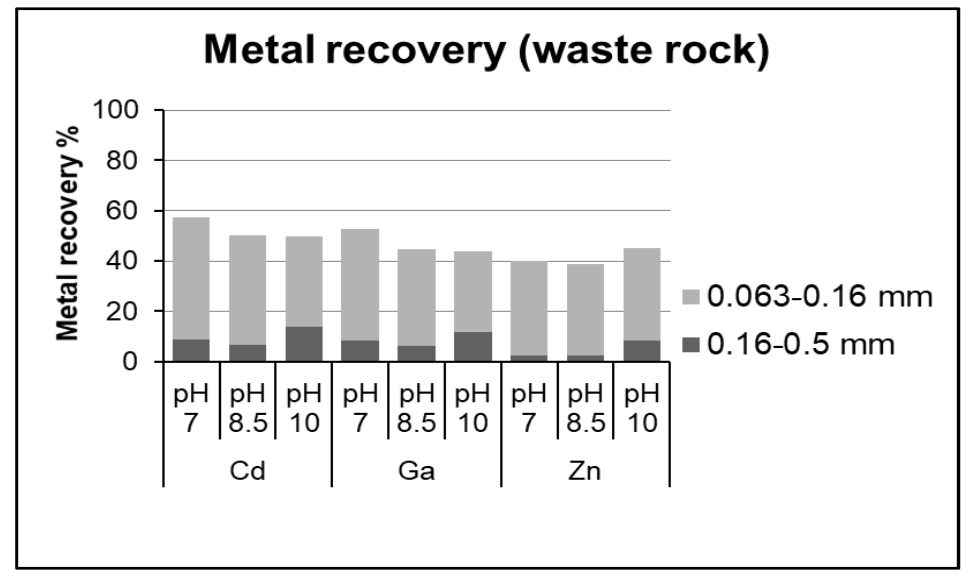

(c)

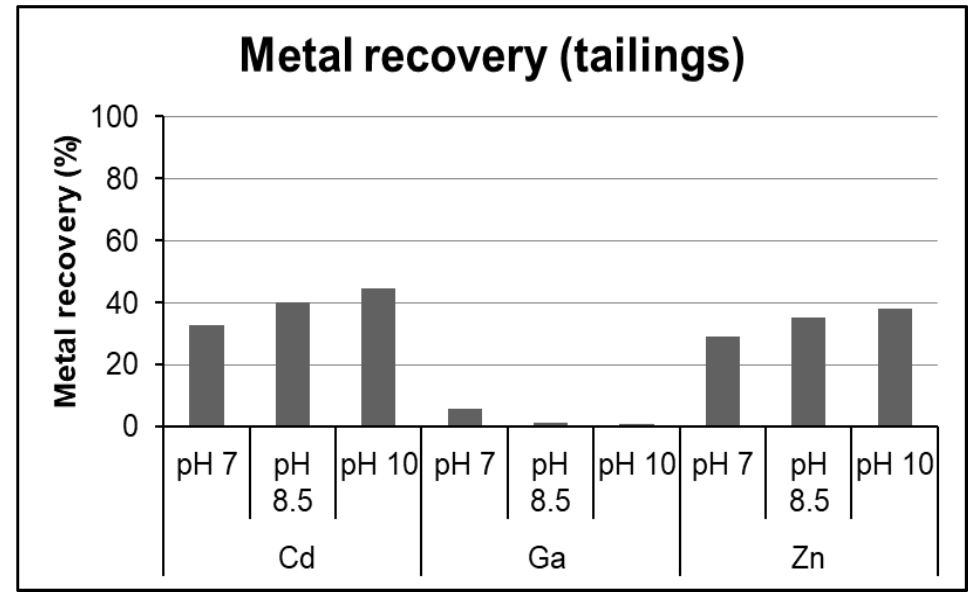

Figure 10. Weight recovery (a) and recovery of $\mathrm{Cd}, \mathrm{Ga}$, and $\mathrm{Zn}$ after treatment of waste rock $(\mathbf{b})$ and tailings (c) at $\mathrm{pH} 7,8.5,10$ and reagent dosage of $1 \mathrm{~g} / \mathrm{kg}$. 
The flotation experiments on the waste rock in the size range fractions $0.16-0.5 \mathrm{~mm}$ were conducted using continuous addition of reagent dosage (as shown in Figure 6). Consequently, the results were obtained using cumulative recovery using Equations (5)-(10). It was observed that the values of cumulative recovery in terms of weight (Figure 11a) varied from $9 \%$ to $83 \%$. The weight recovery indicated that there was higher recovery obtained with subsequent addition of reagent in the slurry at all the three $\mathrm{pH}$ conditions. This has been found in agreement with the previous research done on recovery of zinc from tailings of $\mathrm{Pb}-\mathrm{Zn}$ mines [63]. Similar trends were observed for variation of cumulative recovery of $\mathrm{Cd}, \mathrm{Ga}$, and $\mathrm{Zn}$. The cumulative recovery of $\mathrm{Zn}$ varied from $2 \%$ to $43 \%, 2 \%$ to $84 \%$ and from $8 \%$ to $33 \%$ for $\mathrm{pH} 7, \mathrm{pH} 8.5$ and $\mathrm{pH} 10$, respectively.

(a)

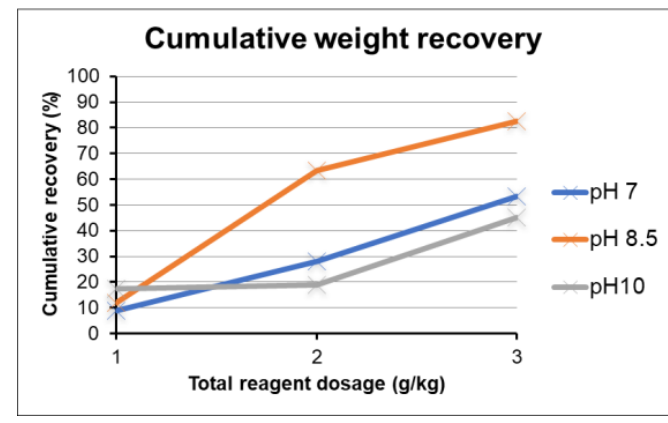

(c)

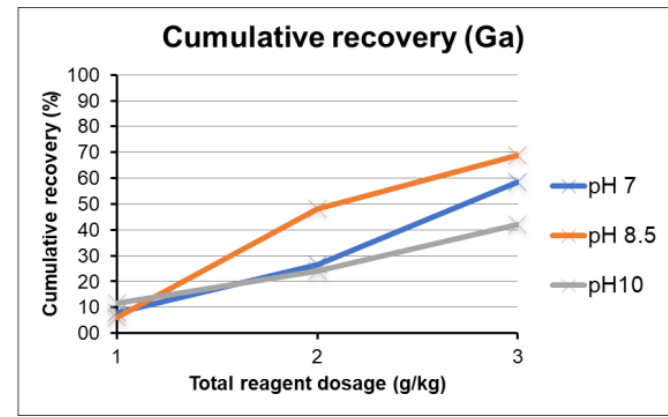

(b)

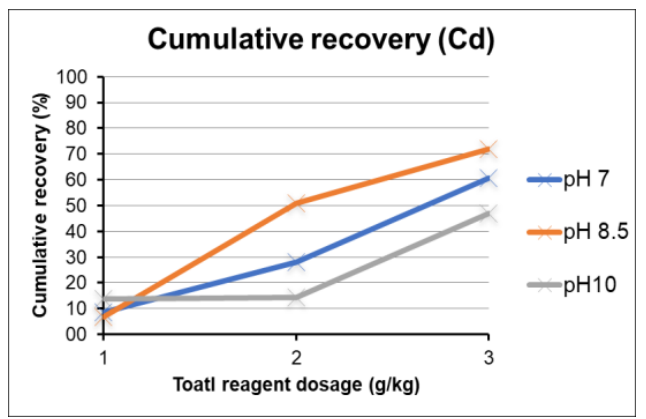

(d)

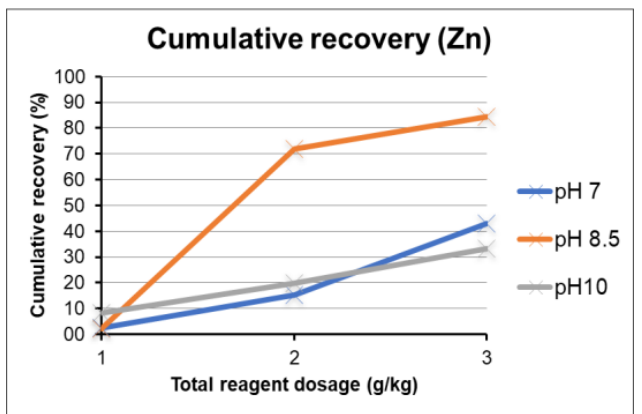

Figure 11. Cumulative weight recovery (a) and cumulative recovery of $\mathrm{Cd}(\mathbf{b}), \mathrm{Ga}(\mathbf{c})$, and $\mathrm{Zn}(\mathbf{d})$, after treatment of waste rock and tailings at $\mathrm{pH} 7,8.5,10$ (calculated using Equations (6)-(10)).

The cumulative recovery at different conditions showed that different $\mathrm{pH}$ leads to different recovery (here $\mathrm{pH} 8.5>\mathrm{pH} 7>\mathrm{pH} 10$ ). The possible reason for this could be that $\mathrm{Zn}^{2+}$ cations (due to $\mathrm{ZnO}, \mathrm{Zn}(\mathrm{OH})_{2}$ species) exhibit a marked effect on the zeta potential if they are present on the sphalerite surface in the region ( $\mathrm{pH} 8-9$ ), making the sphalerite strongly negatively charged at $\mathrm{pH}$ 8-9 [64]. This suggests that flotation experiments were highly affected by $\mathrm{pH}$ and reagent dosage. The other parameters that affect the recovery from any feeding material are the use of depressants, the use of controller, the use of different reagents, the $\mathrm{pH}$ conditions, the electrolytic conductivity of the slurry, the setting up of further beneficiation processes or dressing activities, etc. Thus, prior to setting up of the actual plant, it is necessary that these factors are analyzed on a laboratory scale along with analysis of EW present at the site.

The mineral map of float sample after flotation of waste rock at $\mathrm{pH} 7(<0.5 \mathrm{~mm})$ is given in Figure 12a. The analysis showed that calcite (57.2\%) and smithsonite (27.0\%) were the main minerals and minor minerals were pyrite $(9.3 \%)$ and sphalerite $(6.5 \%)$. The analysis also showed that the minerals were found to be dispersed as very small grains in the sample matrix. 
(a)

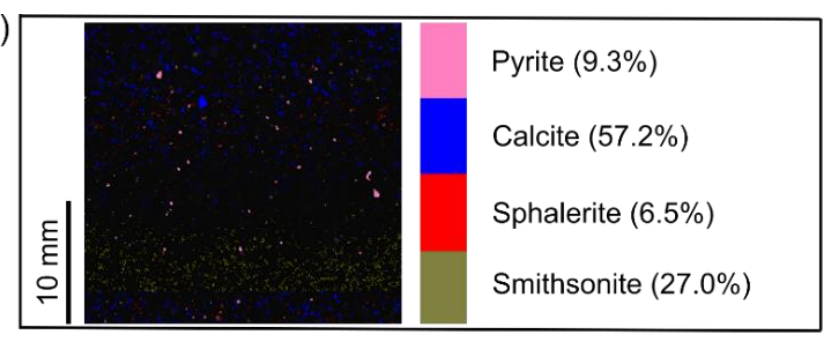

(b)

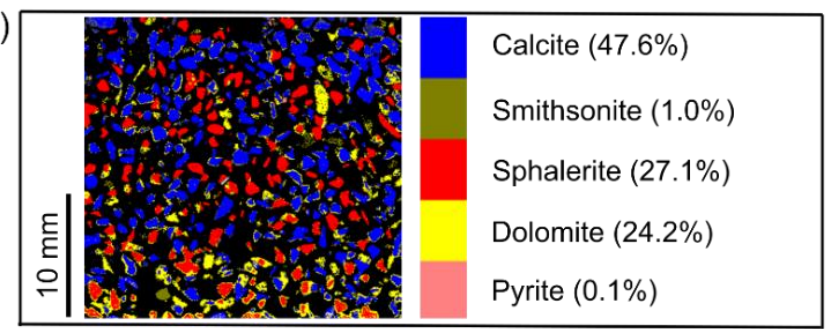

(c)

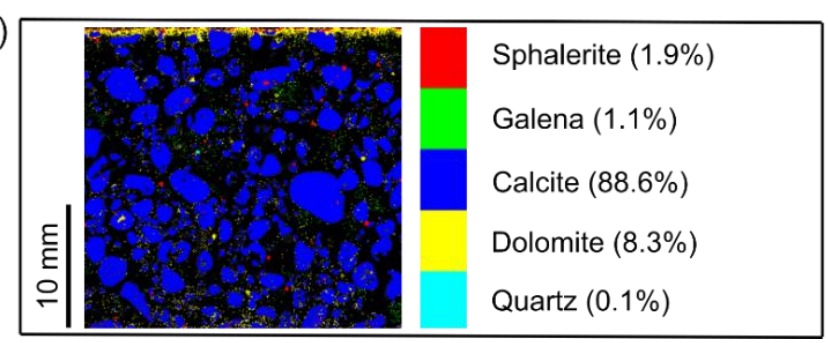

Figure 12. Mineral maps of float samples obtained after flotation at $\mathrm{pH} 7$ of waste rock and tailings: (a) waste rock (size fraction 0.063-0.16 mm, after reagent dosage of $1 \mathrm{~g} / \mathrm{kg}$ ), (b) waste rock (size fraction $0.16-0.5 \mathrm{~mm}$, after reagent dosage of $3 \mathrm{~g} / \mathrm{kg}$ ), and (c) tailings (after reagent dose of $1 \mathrm{~g} / \mathrm{kg}$ ).

The mineral map of float sample obtained after flotation of WR $(0.16-0.5 \mathrm{~mm})$ using $3 \mathrm{~g} / \mathrm{kg}$ reagent dosage is represented in Figure 12b. It shows that abundant minerals obtained were calcite $(47.6 \%)$ and dolomite $(24.2 \%)$ and minor minerals were sphalerite $(27.1 \%)$ and subordinately smithsonite and pyrite, suggesting that WR in size fraction $(0.16-0.5 \mathrm{~mm})$ can be used for recovery of raw materials from sphalerite after using $3 \mathrm{~g} / \mathrm{kg}$ of reagent dosage. This is also evident from increasing cumulative recovery of $\mathrm{Zn}$ with reagent dosage in Figure 11d. Although grain liberation size experiments were not conducted (Section 2.5.3.-Subsamples for Flotation), it should be noted that the results obtained from both the elemental analysis and mineral mapping indicate that $0.16-0.5 \mathrm{~mm}$ showed higher recovery of sphalerite at reagent dosage of $3 \mathrm{~g} / \mathrm{kg}$. Mineral map of float sample after flotation on tailings demonstrated the main mineral to be calcite $(88.6 \%)$ and minor minerals to be dolomite, sphalerite, galena, and quartz with total percentage less than $15 \%$ (Figure 12c). These results show that the concentrate from tailings did not show the presence of sphalerite, which can be exploited economically.

\section{Conclusions}

The present research investigated the reuse potential of the extractive waste present at the abandoned mining site in Gorno (northwestern Italy). This study assessed the impact of fine fractions coming from waste rocks and tailings on plants by using it as a soil additive. On the other hand, the coarse waste rock samples (crushed to various size fractions) and tailings were also dressed using shaking table and flotation. Tailings showed lower recoveries of analyzed elements compared to waste rock in the shaking table experiments. The flotation experiments showed that the recovery for $\mathrm{Cd}$, $\mathrm{Ga}$, and $\mathrm{Zn}$ was less than $50 \%$ for waste rock (in size fractions $0.063-0.16 \mathrm{~mm}$ and $0.16-0.5 \mathrm{~mm}$ ) and tailings samples at reagent dosage of $1 \mathrm{~g} / \mathrm{kg}$ at. However, cumulative recovery was considerably increased by increasing reagent dosage consecutively. On the basis of these experiments, it can be proposed that tailings should be used as soil additive with the addition of fertilizers and amendments 
to soil. However, for the recovery of metals from waste rock samples of Gorno, flotation should be used as the preferred separation method. The current research, thus, provides insights into recovery potential present at the site using wet shaking table and froth flotation. It also lays the foundation for future research, which should analyze other methods of dressing activities and recovery of RM such as bioleaching, hydrometallurgy, oil agglomeration flotation, etc. that can be used on the basis of economic and environmental feasibility, which were not applied in the present work.

Finally, the present investigation frames the opportunities for realizing a sustainable and resilient circular economy for extractive waste management. It is an approach that integrates innovation across geological, soil science, mineralogical, and technological domains. The transformation towards a circular economy needs advancements in filling the knowledge gaps of the factors that affect the way waste is managed. The present work highlights the opportunity to consider extractive waste facilities as "ore bodies" to exploit. Recovery of raw materials can also lead to remediation of the investigated area, decrementing the environmental impacts associated with extractive waste facilities [65]. Thus, the recovery of RM and reclamation operations can be strategically integrated for the requalification and future management of the damaged area [66]. By combining (future) valorization of materials with land re-use, cost efficient resource recovery of extractive waste will potentially generate economic, environmental, and social benefits [7].

Supplementary Materials: The following are available online at http://www.mdpi.com/2071-1050/12/6/2471/s1, S.1. Aqua Regia and DTPA Extractions, S.2. Seed Germination and Plant Growth Experiments, S.3. Quality control measurements of the analysed elements.

Author Contributions: Conceptualization, N.M., G.A.D., and F.A.-M.; methodology, G.A.D., N.M., and I.P. software, N.M., P.R., and I.P., validation, G.A.D., N.M., P.R., and F.A.-M.; formal analysis, N.M., G.A.D., and I.P., investigation, N.M., G.A.D., and I.P.; resources, D.A.D.L., G.A.D., and F.A.M.; data curation, N.M., G.A.D., I.P., and P.R.; writing —original draft preparation, N.M., and G.A.D.; writing—review and editing, N.M., and G.A.D.; visualization, N.M., G.A.D., and I.P.; supervision, G.A.D., D.A.D.L., and F.A.-M.; project administration, G.A.D.; funding acquisition, D.A.D.L., G.A.D., and F.A.-M. All authors have read and agreed to the published version of the manuscript.

Funding: This work was completed as part of the REMEDIATE (Improved decision-making in contaminated land site investigation and risk assessment) Marie-Curie Innovation Training Network, which received funding from the European Union's Horizon 2020 Programme for research, technological development and demonstration under grant agreement no. 643087. Sincere thanks to UKRI-EPSRC for financially supporting N.M. to pursue research in circular economy through the ACCEPT Transitions project based at Queen's University Belfast (ref. no. $\mathrm{EP} / \mathrm{S} 025545 / 1)$.

Acknowledgments: This article is dedicated to the memory of Piergiorgio Rossetti, Università degli Studi di Torino. Many thanks to Lorena Zichella, Rossana Bellopede, and Paola Marini (Politecnico Di Torino) for helping with recovery experiments and Chiara Groppo and Roberto Cossio (Università degli Studi di Torino) for their help in acquiring and processing the multielemental micro-XRF maps.

Conflicts of Interest: The authors declare no conflict of interest

\section{References}

1. Ali, S.H.; Giurco, D.; Arndt, N.; Nickless, E.; Brown, G.; Demetriades, A.; Durrheim, R.; Enrique, M.A.; Kinnaird, J.; Littleboy, A.; et al. Mineral supply for sustainable development requires resource governance. Nature 2017, 543, 367-372. [CrossRef] [PubMed]

2. Kinnunen, P.H.M.; Kaksonen, A.H. Towards circular economy in mining: Opportunities and bottlenecks for tailings valorization. J. Clean. Prod. 2019, 228, 153-160. [CrossRef]

3. Kawamoto, H. Japan's policies to be adopted on rare metal resources. Sci. Tech. Trends. 2008, 27, 57-76.

4. US National Research Council; Committee on Critical Mineral Impacts of the U.S.; Economy, Committee on Earth Resources. Minerals, Critical Minerals, and the U.S. Economy; The National Academies Press: Washington, DC, USA, 2008.

5. European Commission. Report on Critical Raw Materials and the Circular Economy. Available online: http: //publications.europa.eu/resource/cellar/d1be1b43-e18f-11e8-b690-01aa75ed71a1.0001.01/DOC_1 (accessed on 20 March 2020). 
6. Hennebel, T.; Boon, N.; Maes, S.; Lenz, M. Biotechnologies for critical raw material recovery from primary and secondary sources: R\&D priorities and future perspectives. New Biotechnol. 2015, 32, 121-127.

7. Jones, P.T.; Geysen, D.; Tielemans, Y.; Van Passel, S.; Pontikes, Y.; Blanpain, B.; Quaghebeur, M.; Hoekstra, N. Enhanced Landfill Mining in view of multiple resource recovery: A critical review. J. Clean. Prod. 2013, 55, 45-55. [CrossRef]

8. European Commission. Closing the Loop - An EU Action Plan for the Circular Economy; European Commission: Brussels, Belgium, 2015.

9. European Commission. The Circular Economy Action Plan; European Commission: Brussels, Belgium, 2019.

10. Blengini, G.; Mathieux, F.; Mancini, L.; Nyberg, M.; Cavaco Viegas, H.; Salminen, J.; Garbarino, E.; Orveillon, G.; Saveyn, H.; Mateos Aquilino, V.; et al. Recovery of Critical and Other Raw Materials from Mining Waste and Landfills. Available online: https://www.kriittisetmateriaalit.fi/wp-content/uploads/2019/ 08/aaa_20190506-d3-jrc-science-for-policy-recovery_of_rm_from_mining_waste_and_landfills_4_07_19_o nline_final.pdf (accessed on 20 March 2020).

11. Burlakovs, J.; Jani, Y.; Kriipsalu, M.; Vincevica-Gaile, Z.; Kaczala, F.; Celma, G.; Ozola, R.; Rozina, L.; Rudovica, V.; Hogland, M. On the way to 'zero waste' management: Recovery potential of elements, including rare earth elements, from fine fraction of waste. J. Clean. Prod. 2018, 186, 81-90. [CrossRef]

12. Dino, G.A.; Rossetti, P.; Biglia, G.; Sapino, M.L.; Di Mauro, F.; Särkkä, H.; Coulon, F.; Gomes, D.; Parejo-Bravo, L.; Aranda, P.Z.; et al. Smart ground project: A new approach to data accessibility and collection for raw materials and secondary raw materials in Europe. Environ. Eng. Manag. J. 2017, 16, 1673-1684. [CrossRef]

13. Bian, Z.; Miao, X.; Lei, S.; Chen, S.; Wang, W.; Struthers, S. The challenges of reusing mining and mineral-processing wastes. Science 2012, 337, 702-703. [CrossRef]

14. Karaca, O.; Cameselle, C.; Reddy, K.R. Mine tailing disposal sites: Contamination problems, remedial options and phytocaps for sustainable remediation. Rev. Environ. Sci. Biotechnol. 2018, 17, 205-228. [CrossRef]

15. Karlsson, T.; Räisänen, M.L.; Lehtonen, M.; Alakangas, L. Comparison of static and mineralogical ARD prediction methods in the Nordic environment. Environ. Monit. Assess. 2018, 190, 719. [CrossRef]

16. Kaupilla, P.M.; Tarvainen, T. Improving the Environmental Properties, Utilisation and Long-Term Prediction of Mining Wastes; Geological Survey of Finland: Espoo, Finland, 2018; Bulletin 408.

17. Abaka-Wood, G.B.; Zanin, M.; Addai-Mensah, J.; Skinner, W. Recovery of rare earth elements minerals from iron oxide-silicate rich tailings-Part 2: Froth flotation separation. Miner. Eng. 2019, 142, 105888. [CrossRef]

18. Bruneel, O.; Mghazli, N.; Sbabou, L.; Héry, M.; Casiot, C.; Filali-Maltouf, A. Role of microorganisms in rehabilitation of mining sites, focus on Sub Saharan African countries. J. Geochem. Explor. 2019, 205, 106327. [CrossRef]

19. Festin, E.S.; Tigabu, M.; Chileshe, M.N.; Syampungani, S.; Odén, P.C. Progresses in restoration of post-mining landscape in Africa. J. For. Res. 2019, 30, 381-396. [CrossRef]

20. Mathieux, F.; Ardente, F.; Bobba, S.; Nuss, P.; Blengini, G.; Alves Dias, P.; Blagoeva, D.; Torres De Matos, C.; Wittmer, D.; Pavel, C.; et al. Critical Raw Materials and the Circular Economy-Background Report; JRC Science-for-policy report, EUR 28832 EN; Publications Office of the European Union: Luxembourg, 2017; ISBN 978-92-79-74282-8. [CrossRef]

21. Banks, D.; Younger, P.L.; Arenesen, R.; Iversen, E.R.; Banks, S.B. Mine-water chemistry: The good, the bad and the ugly. Environ. Geol. 1997, 32, 157-174. [CrossRef]

22. van Zyl, D.; Shields, D.; Agioutantis, Z.; Joyce, S. Waste not, want not-rethinking the tailings and mine waste issue. AusImm Bull. December 2016. Conference paper. Available online: https://www.ausimmbulletin.com/f eature/waste-not-want-not-rethinking-the-tailings-and-mine-waste-issue/ (accessed on 20 March 2020).

23. Cooke, J.A.; Johnson, M.S. Ecological restoration of land with particular reference to the mining of metals and industrial minerals. Environ. Rev. 2002, 10, 41-71. [CrossRef]

24. Jiangang, F.; Kaida, C.; Hui, W.; Chao, G.; Wei, L. Recovering molybdenite from ultrafine waste tailings by oil agglomerate flotation. Miner. Eng. 2012, 39, 133-139. [CrossRef]

25. Ghosh, S.; Das, A.P. Bioleaching of manganese from mining waste residues using Acinetobacter sp. Geol. Ecol. Landsc. 2017, 1, 77-83. [CrossRef]

26. Henne, A.; Craw, D.; Vasconcelos, P.; Southam, G. Bioleaching of waste material from the Salobo mine, Brazil: Recovery of refractory copper from Cu hosted in silicate minerals. Chem. Geol. 2018, 498, 72-82. [CrossRef] 
27. Stewart, B.W.; Capo, R.C.; Hedin, B.C.; Hedin, R.S. Rare earth element resources in coal mine drainage and treatment precipitates in the Appalachian Basin, USA. Int. J. Coal Geol. 2017, 169, 28-39. [CrossRef]

28. Afum, B.O.; Caverson, D.; Ben-Awuah, E. A conceptual framework for characterizing mineralized waste rocks as future resource. Int. J. Min. Sci. Technol. 2019, 29, 429-435. [CrossRef]

29. Ceniceros-Gómez, A.E.; Macías-Macías, K.Y.; de la Cruz-Moreno, J.E.; Gutiérrez-Ruiz, M.E.; Martínez-Jardines, L.G. Characterization of mining tailings in México for the possible recovery of strategic elements. J. S. Am. Earth Sci. 2018, 88, 72-79. [CrossRef]

30. Martin, M.; Janneck, E.; Kermer, R.; Patzig, A.; Reichel, S. Recovery of indium from sphalerite ore and flotation tailings by bioleaching and subsequent precipitation processes. Miner. Eng. 2015, 75, 94-99. [CrossRef]

31. Pactwa, K.; Woźniak, J.; Strempski, A. Sustainable mining-Challenge of Polish mines. Resour. Policy. 2018. Available online: https://doi.org/10.1016/j.resourpol.2018.09.009 (accessed on 25 September 2018.).

32. MISE. Towards a Model of Circular Economy for Italy-Overview and Strategic Framework. Italian Ministry of Economic Development and Ministry of Environment, Land \& Sea. Available online: https: //circulareconomy.europa.eu/platform/en/strategies (accessed on 15 January 2020).

33. Dino, G.A.; Rossetti, P.; Perotti, P.; Alberto, W.; Sarkka, H.; Coulon, F.; Wagland, S.; Griffiths, Z.; Rodeghiero, F. Sustainable management and exploitation of extractive waste: Towards a more efficient resource preservation and waste recycling. In Landfill Mining from Extractive Waste Facilities: The Importance of A Correct Site Characterisation and Evaluation of the Potentialities. A Case Study from Italy; Elsevier: Amsterdam, The Netherlands, 2018; pp. 50-61.

34. Assereto, R.; Jadoul, F.; Ometto, P. Stratigrafia e metallogenesi del settore occidentale del distretto a Pb, Zn, fluorite e barite di Gorno (Alpi Bergamasche). Rev. Ital. Paleontol. Stratigr. 1977, 83, 395-532.

35. Omenetto, P.; Vailati, G. Ricerche geominerarie nel settore centrale del distretto a $\mathrm{Pb}-\mathrm{Zn}$, fluorite e barite di Gorno (Lombardia). L'Industria Min. 1977, 28, 25-44.

36. Rodeghiero, F.; Vailati, G. Nuove osservazioni sull'assetto geologico-strutturale del settore centrale del distretto piombo-zincifero di Gorno (Alpi Bergamasche). L'Industria Min. 1978, 29, 298-302.

37. Beltrando, M.; Stockli, D.F.; Decarlis, A.; Manatschal, G. A crustal-scale view at rift localization along the fossil Adriatic margin of the Alpine Tethys preserved in NW Italy. Tectonics 2015, 34, 1927-1951. [CrossRef]

38. U.S. EPA. 2007. Method 3051A (SW-846): Microwave Assisted Acid Digestion of Sediments, Sludges, and Oils. Available online: https://www.epa.gov/sites/production/files/2015-12/documents/3051a.pdf (accessed on 20 March 2020).

39. U.S. EPA. 2014. Method 6010D (SW-846): Inductively Coupled Plasma-Atomic Emission Spectrometry. Available online: https://www.epa.gov/sites/production/files/2015-12/documents/6010d.pdf (accessed on 20 March 2020).

40. Lindsay, W.L.; Norvell, W.A. Development of a DTPA soil test for zinc, iron, manganese, and copper. J. Soil. Sci. Soc. Am. 1978, 42, 421-428. [CrossRef]

41. Wundram, M.; Selmar, D.; Bahadir, M. Representation evaluation of Phytotoxicity-Reliability and Peculiarities. Angew. Bot. 1997, 71, 139-143.

42. Blok, C.; Perssone, G.; Wever, G. A practical and low cost microbiotest to assess the phytotoxic potential of growing media and soil. ISHS Acta Horticulturae 779. Int. Soc. Hortic. Sci. 2008, 367-374. [CrossRef]

43. Cossio, R.; Borghi, A.; Ruffini, R. Quantitative modal determination of geological samples based on X-ray multielemental map acquisition. Microsc. Microanal. 2002, 8, 139-149. [CrossRef]

44. Zhao, Y.; Zhang, Y.; Bao, S.; Liu, T.; Bian, Y.; Liu, X.; Jiang, M. Separation factor of shaking table for vanadium pre-concentration from stone coal. Sep. Purif. Technol. 2013, 115, 92-99. [CrossRef]

45. Rahman, R.M.; Ata, S.; Jameson, G.J. Froth recovery measurements in an industrial flotation cell. Miner. Eng. 2013, 53, 193-202. [CrossRef]

46. Ballantyne, G.R.; Holtham, P.N. Application of dielectrophoresis for the separation of minerals. Miner. Eng. 2010, 23, 350-358. [CrossRef]

47. Rao, S.R.; Leja, J. Surface Chemistry of Froth Flotation, 2nd ed.; Kluwer Academic Publication: New York, NY, USA, 2004.

48. Neethling, S.J.; Cilliers, J.J. The entrainment factor in froth flotation: Model for particle size and other operating parameter effects. Int. J. Miner. Process. 2009, 93, 141-148. [CrossRef]

49. Wang, L.; Peng, Y.; Runge, K.; Bradshaw, D. A review of entrainment: Mechanisms, contributing factors and modelling in flotation. Miner. Eng. 2015, 70, 77-91. [CrossRef] 
50. Brezáni, I.; Škvarla, J.; Sisol, M. Reverse froth flotation of magnesite ore by using (12-4-12) cationic gemini surfactant. Miner. Eng. 2017, 110, 65-68. [CrossRef]

51. Chen, X.; Peng, Y.; Bradshaw, D. The separation of chalcopyrite and chalcocite from pyrite in cleaner flotation after regrinding. Miner. Eng. 2014, 58, 64-72. [CrossRef]

52. Caporale, A.G.; Adamo, P.; Capozzi, F.; Langella, G.; Terribile, F.; Vingiani, S. Monitoring metal pollution in soils using portable-XRF and conventional laboratorybased techniques: Evaluation of the performance and limitations according to metal properties and sources. Sci. Total Environ. 2018, 643, 516-526. [CrossRef]

53. Adamo, P.; Agrelli, D.; Zampella, M. Chemical speciation to assess bioavailability, bioaccessibility and geochemical forms of potentially toxic metals (PTMs) in polluted soils. In Environmental Geochemistry, Site Characterization, Data Analysis and Case Hystories, 2nd ed.; De Vivo, B., Belkin, H.E., Lima, A., Eds.; Elsevier: Amsterdam, The Netherlands, 2018; Chapter 9.

54. Khelifi, F.; Besser, H.; Ayadi, Y.; Liu, G.; Yousaf, B.; Harabi, S.; Bedoui, S.; Zighmi, K.; Hamed, Y. Evaluation of potentially toxic elements' (PTEs) vertical distribution in sediments of Gafsa-Metlaoui mining basin (Southwestern Tunisia) using geochemical and multivariate statistical analysis approaches. Environ. Earth Sci. 2019, 78, 53. [CrossRef]

55. Ministero dell'Ambiente e della Tutela del Territorio. Gazzetta Ufficiale n. 88 of 14 Aprile 2006 Decreto Legislativo 3 Aprile 2006, Suppl. Ordinario n. 96, n. 152"Norme in Materia Ambientale.". p. 630. Available online: https://www.minambiente.it/sites/default/files/archivio/normativa/dlgs_03_04_2006_152.pdf (accessed on 20 March 2020).

56. Antoniadis, V.; Levizou, E.; Shaheen, S.M.; Ok, Y.S.; Sebastian, A.; Baum, C.; Prasad, M.N.V.; Wenzel, W.W.; Rinklebe, J. Trace elements in the soil-plant interface: Phytoavailability, translocation, and phytoremediation-A review. Earth-Sci. Rev. 2017, 171, 621-645. [CrossRef]

57. Das, P.; Samantaray, S.; Rout, G.R. Studies on cadmium toxicity in plants: A review. Environ. Pollut. 1997, 98, 29-36. [CrossRef]

58. Olowoyo, J.O.; Okedeyi, O.O.; Mkolo, N.M.; Lion, G.N.; Mdakane, S.T.R. Uptake and translocation of heavy metals by medicinal plants growing around a waste dump site in Pretoria, South Africa. S. Afr. J. Bot. 2012, 78, 116-121. [CrossRef]

59. Dalmora, A.C.; Ramos, C.G.; Silva Oliveira, M.L.; Silva Oliveira, L.F.; Homrich Schneider, I.A.; Kautzmann, R.M. Application of andesite rock as a clean source of fertilizer for eucalyptus crop: Evidence of sustainability. J. Clean. Prod. 2020, 256, 120432. [CrossRef]

60. Yao, Q.; Wang, X.; Jian, H.; Chen, H.; Yu, Z. Characterization of the Particle Size Fraction associated with Heavy Metals in Suspended Sediments of the Yellow River. Int. J. Environ. Res. Public Health 2015, 12, 6725-6744. [CrossRef]

61. Kademli, M.; Gulsoy, O.Y. The role of particle size and solid contents of feed on mica-feldspar separation in gravity concentration. Physicochem. Probl. Miner. Process. 2012, 48, 645-654.

62. Yu, Y.; Ma, L.; Cao, M.; Liu, Q. Slime coatings in froth flotation: A review. Miner. Eng. 2017, 114, $26-36$. [CrossRef]

63. Navidi Kashani, A.H.; Rashchi, F. Separation of oxidized zinc minerals from tailings: Influence of flotation reagents. Miner. Eng. 2008, 21, 967-972. [CrossRef]

64. Mirnezami, M.; Restrepo, L.; Finch, J.A. Aggregation of sphalerite: Role of zinc ions. J. Colloid. Interface Sci. 2003, 259, 36-42. [CrossRef]

65. Danthurebandara, M.; Van Passel, S.; Vanderreydt, I.; Van Acker, K. Assessment of environmental and economic feasibility of Enhanced Landfill Mining. Waste Manag. Elsevier 2015, 45, 434-447. [CrossRef]

66. Yi, S. Resource recovery potentials by landfill mining and reclamation in South Korea. J. Environ. Manag. Elsevier 2019, 242, 178-185. [CrossRef]

(C) 2020 by the authors. Licensee MDPI, Basel, Switzerland. This article is an open access article distributed under the terms and conditions of the Creative Commons Attribution (CC BY) license (http://creativecommons.org/licenses/by/4.0/). 